\title{
Stratification of surface waters during the last glacial millennial climatic events: a key factor in subsurface and deep-water mass dynamics
}

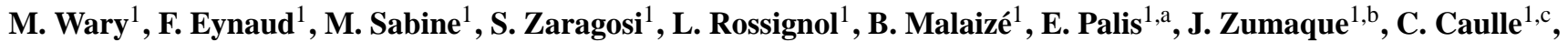 \\ A. Penaud ${ }^{2}$, E. Michel $^{3}$, and K. Charlier ${ }^{1}$ \\ ${ }^{1}$ UMR 5805, EPOC (Environnements et Paléoenvironnements Océaniques et Continentaux), Université de Bordeaux, \\ 33615 Pessac, France \\ ${ }^{2}$ UMR 6538, Domaines Océaniques, IUEM-UBO, 29280 Plouzané, France \\ ${ }^{3}$ UMR 8212, LSCE (Laboratoire des Sciences du Climat et de l'Environnement), CEA/CNRS-INSU/UVSQ, \\ 91198 Gif-sur-Yvette CEDEX, France \\ anow at: UMR 7329, Géoazur, Université de Sophia Antipolis, 06560 Valbonne, France \\ ${ }^{\mathrm{b}}$ now at: UQAM, Université du Québec à Montreal, Montréal, Québec H3C 3P8, Canada \\ c now at: Laboratoire Péagos, Département Dynamiques des écosystèmes cô̂tiers, IFREMER Brest, Technopô^le Brest Iroise, \\ 29280 Plouzané, France
}

Correspondence to: M. Wary (melanie.wary@u-bordeaux.fr)

Received: 25 April 2015 - Published in Clim. Past Discuss.: 29 May 2015

Revised: 19 August 2015 - Accepted: 18 October 2015 - Published: 12 November 2015

\begin{abstract}
The last glacial period was punctuated by abrupt climatic events with extrema known as Heinrich and Dansgaard-Oeschger events. These millennial events have been the subject of many paleoreconstructions and model experiments in the past decades, but yet the hydrological processes involved remain elusive. In the present work, highresolution analyses were conducted on the 12-42 ka BP section of core MD99-2281 retrieved southwest of the Faeroe Islands, and combined with analyses conducted in two previous studies (Zumaque et al., 2012; Caulle et al., 2013). Such a multiproxy approach, coupling micropaleontological, geochemical and sedimentological analyses, allows us to track surface, subsurface, and deep hydrological processes occurring during these rapid climatic changes. Records indicate that the coldest episodes of the studied period (Greenland stadials and Heinrich stadials) were characterized by a strong stratification of surface waters. This surface stratification seems to have played a key role in the dynamics of subsurface and deep-water masses. Indeed, periods of high surface stratification are marked by a coupling of subsurface and deep circulations which sharply weaken at the beginning of stadials, while surface conditions progressively deterio-
\end{abstract}

rate throughout these cold episodes; conversely, periods of decreasing surface stratification (Greenland interstadials) are characterized by a coupling of surface and deep hydrological processes, with progressively milder surface conditions and gradual intensification of the deep circulation, while the vigor of the subsurface northward Atlantic flow remains constantly high. Our results also reveal different and atypical hydrological signatures during Heinrich stadials (HSs): while HS1 and HS4 exhibit a "usual" scheme with reduced overturning circulation, a relatively active North Atlantic circulation seems to have prevailed during HS2, and HS3 seems to have experienced a re-intensification of this circulation during the middle of the event. Our findings thus bring valuable information to better understand hydrological processes occurring in a key area during the abrupt climatic shifts of the last glacial period.

\section{Introduction}

The last glacial period is characterized by abrupt climate oscillations. This millennial to sub-millennial climatic variability was first evidenced in Greenland atmospheric tem- 
perature records as oscillations occurring every $1-4 \mathrm{ka}$ and known as Dansgaard-Oeschger (DO) cycles (Dansgaard et al., 1993, Bond et al., 1993). DO cycles are characterized by a rapid warming occurring in a few decades into a warm phase (Greenland interstadial - GI), followed by a more progressive cooling back into a cold phase (Greenland stadial - GS). These cycles have been widely identified in marine archives from the subpolar North Atlantic Ocean and adjacent seas as coeval changes in surface and deep hydrology (e.g., Rasmussen et al., 1996a, b; Kissel et al., 1999; Van Kreveld et al., 2000; Rahmstorf, 2002). Moreover, during GSs (including the most massive, i.e., Heinrich stadials - HSs), increases in iceberg and ice-rafted debris (IRD) delivery from the boreal ice sheets are recorded (e.g., Heinrich, 1988; Bond et al., 1993; Bond and Lotti, 1995; Elliot et al., 2001). Despite a large number of paleoreconstructions and model experiments focusing on this millennial climatic variability, processes involved still remain elusive and different mechanisms are invoked. Most of the considered theories involve changes in the meridional overturning circulation, either as the cause (e.g., Alvarez-Solas et al., 2010) or the consequence (e.g., Manabe and Stouffer, 1995; Ganopolski and Rahmstorf, 2001; Levine and Bigg, 2008) of these periodic ice-sheet instabilities.

In order to better understand these phenomena, the importance of working on high-resolution records coming from key locations has been highlighted. Previous studies of marine cores located around major sills in between the North Atlantic Ocean and the Nordic Seas have shown the strong potential of this buffer area to track this variability (see references herein). Most of these studies agree with coeval oscillations of the meridional overturning circulation, depicted as a weaker loop of Atlantic inflow and deep overflow from the Nordic Seas during GSs and HSs and the opposite during GIs (e.g., Rasmussen et al., 1996a, b, 2002a; Moros et al., 1997, 2002; Kissel et al., 1999, 2008; Van Kreveld et al., 2000; Elliot et al., 2002; Rasmussen and Thomsen, 2004; Ballini et al., 2006; Dickson et al., 2008). Some of them (Rasmussen et al., 1996a, b; Rasmussen and Thomsen, 2004; Van Kreveld et al., 2000; Dokken et al., 2013), on the basis of indirect proxies of sea-surface conditions, suggest a strong stratification of the water column and the presence of a halocline during GSs, which might have affected the oceanic circulation at greater depths.

Our study uses proxies that give access to (sub)surface (foraminifera assemblages and geochemical analyses on their shells) and deep-water mass dynamics (sediment grain-size measurements and magnetic susceptibility), coupled to previously published reconstructions of sea-surface sensu stricto conditions obtained from dinoflagellate cyst (dinocyst) assemblages (Zumaque et al., 2012; Caulle et al., 2013). All analyses were conducted at centennial to millennial timescales on core MD99-2281 located southwest of the Faeroe Islands. This multiproxy approach allows us (i) to directly evidence the past structure of the upper water column, and more specifically to evidence whether stratification did occur; (ii) to track the evolution of the stratification during the millennial abrupt events; and (iii) to evaluate its interaction with subsurface and bottom circulations.

\section{Environmental setting and paleoceanographic interests}

Core MD99-2281 $\left(60.3418^{\circ} \mathrm{N}, 9.4557^{\circ} \mathrm{W} ; 1197 \mathrm{~m}\right.$ water depth) was retrieved during the IMAGES V - GINNA cruise on the RV Marion Dufresne (Labeyrie et al., 1999). The coring site is located southwest of the Faeroe Islands, at the southern foot of the Faeroe Bank and north of the Rockall Trough (Fig. 1).

This area constitutes a nodal point regarding modern oceanic circulation, as it is influenced by (i) the warm and salty Atlantic surface waters $\left(T>5^{\circ} \mathrm{C}, S>35.0\right.$; Hansen and Osterhus, 2000) conveyed by the poleward current of the North Atlantic Drift (NAD), and (ii) the intermediate and deep, cold and less saline waters $\left(T<3{ }^{\circ} \mathrm{C}, S<35.0\right.$; Hansen and Osterhus, 2000) overflowing from the Nordic Seas (e.g., Kuijpers et al., 1998a, b, 2002; Hansen and Osterhus, 2000) (Fig. 1). These intermediate and deep-water masses are formed within the Nordic Seas and are usually grouped under the name of Iceland-Scotland Overflow Water (ISOW; Borenäs and Lundberg, 2004). At present, a branch of ISOW exits the Norwegian Sea by flowing southward through the Faeroe-Shetland Channel and then is divided into two branches: a northern, major and permanent branch and a southern, minor and non-permanent one (Fig. 1b). Our site is located beneath the southern branch, which intermittently crosses the Wyville Thompson Ridge (a topographic barrier culminating at around $600 \mathrm{~m}$ water depth) and flows southward (e.g., Boldreel et al., 1998; Kuijpers et al., 1998a, b, 2002; Hansen and Østerhus, 2000). Nevertheless, according to Boldreel et al. (1998), the coring site is located within the area unaffected by strong current activities, with sedimentation resulting from pelagic sediments deposited in a low-energy, deep-water environment.

This system of water mass exchange is known to have been very sensitive to the millennial-scale climatic variability of the last glacial period (e.g., Rasmussen et al., 1996a, b, 2002a; Moros et al., 1997, 2002; Kissel et al., 1999, 2008; Van Kreveld et al., 2000; Elliot et al., 2002; Eynaud et al., 2002; Rasmussen and Thomsen, 2004, 2008; Ballini et al., 2006; Dickson et al., 2008; Zumaque et al., 2012; Caulle et al., 2013). This is particularly true for the Faeroe region, which was at that time under the direct influence of the proximal European ice sheets (i.e., the Fennoscandian and the British-Irish ice sheets; Fig. 1a) whose decays/build-up have modulated the oceanic and climatic dynamics. Therefore, core MD99-2281 is expected to have recorded changes in the vigor of the NAD penetration and ISOW overflow in relation to European ice-sheet history. 

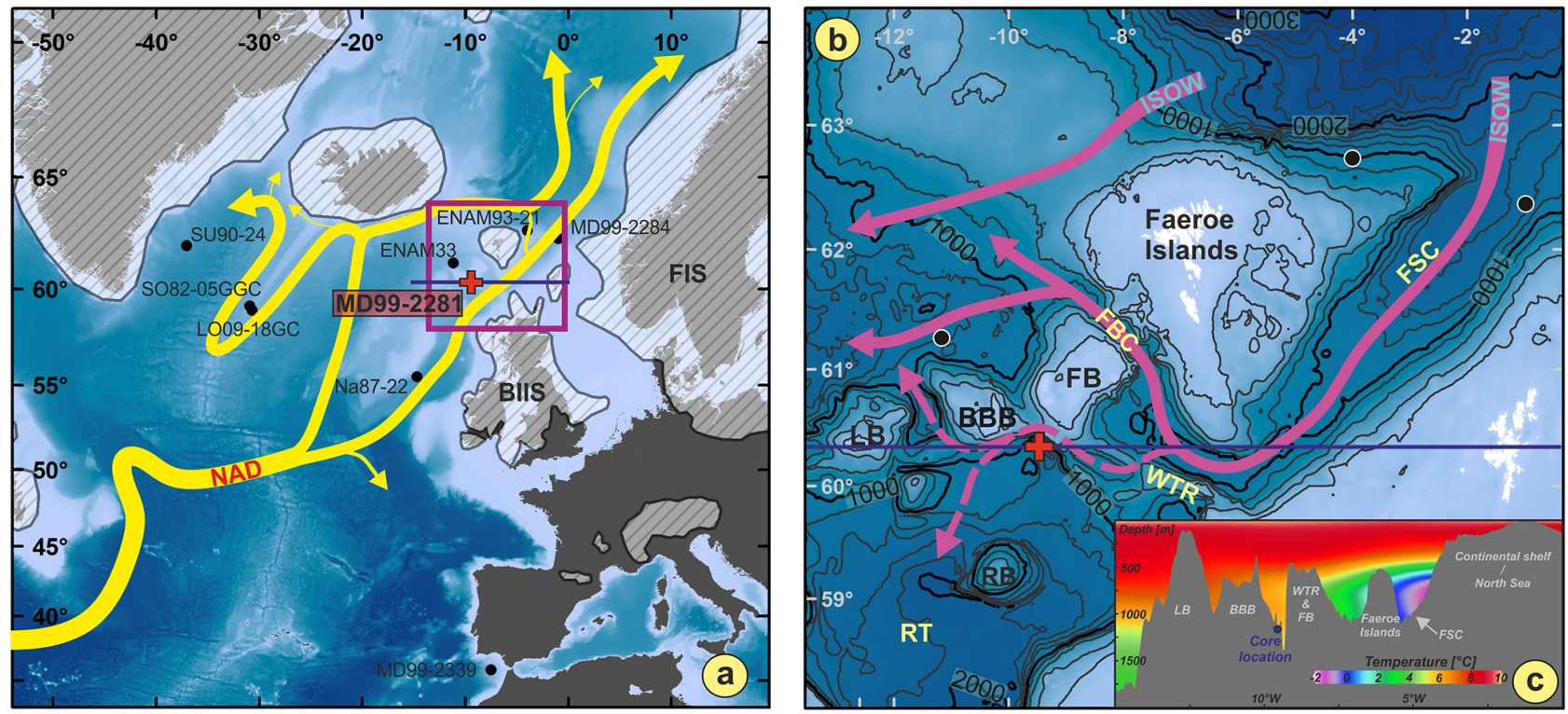

Figure 1. (a) General map of the studied area, showing the location of the studied core MD99-2281 (red cross) and of nearby cores referred to in the present study (black dots - ENAM93-21 and ENAM33: Rasmussen et al., 1996a, b, and Rasmussen and Thomsen , 2004; MD99-2284: Dokken et al., 2013; LO09-18GC and SO82-05GGC, Snowball and Moros, 2003; Na87-22 and SU90-24: Elliot et al, 2002). The hatched areas represent the maximal last glacial extension of the proximal ice sheets (after Ehlers and Gibbard, 2007; FIS: Fennoscandian Ice Sheet; BIIS: British-Irish Ice Sheet). The yellow arrows indicate the major pathways of the warm and saline surface water conveyed by the North Atlantic Drift (NAD, after Orvik and Niiler, 2002, and Stanford et al., 2011). The purple square indicates the area shown in Fig. 1b. The blue line indicates the location of the profile shown in Fig. 1c. (b) Detailed physiography of the studied area. Bathymetry is from GEBCO (www.gebco.net, isobaths every $200 \mathrm{~m}$ ). Remarkable submarine structures are indicated (bathymetric heights: FB, Faeroe Bank; BBB, Bill Bailey Bank; LB, Lousy Bank; and WTR, Wyville Thompson Ridge - RT stands for Rockall Trough, and FSC and FBC for Faeroe-Shetland Channel and Faeroe Bank Channel, respectively). Purple arrows show the major (full lines) and intermittent (dotted lines) deep IcelandScotland Overflow Water (ISOW) pathways, after Boldreel et al. (1998), Kuijpers et al. (1998b, 2002), and Howe et al. (2006). The blue line indicates the location of the profile shown in Fig. 1c. (c) East-west profile of oceanic temperatures. Temperature data are derived from WOA09 (Locarnini et al., 2010) and plotted using Ocean Data View (Schlitzer, 2012); bathymetric data are from GEBCO (www.gebco.net). Locations of the studied core and of the main submarine structures are indicated. Geographic coordinate system: WGS 1984; projection: Mercator $55^{\circ} \mathrm{N}$.

\section{Material and methods}

\subsection{Stratigraphy of the core}

The age model of core MD99-2281 conforms to the previous published one from Zumaque et al. (2012) and Caulle et al. (2013). As recommended by several paleoceanographic studies in this area (e.g., Kissel et al., 1999, 2008; Laj et al., 2000; Elliot et al., 2002; Eynaud et al., 2002; Ballini et al., 2006; Rasmussen and Thomsen, 2009; Dokken et al., 2013), the age model is constrained by AMS ${ }^{14} \mathrm{C}$ dates (in the case of our study, 10 dates measured on planktonic foraminifera monospecific samples), combined with additional tie points (18 in our case) obtained by comparing the magnetic susceptibility record of core MD99-2281 to the $\delta^{18} \mathrm{O}$ signal of NGRIP ice core (GICC05 timescale; Andersen et al., 2006; Svensson et al., 2008; Wolff et al., 2010; see Figs. 2, 3, 4 and 5 , where dates are illustrated by red stars and tie points by blue stars along the age axis). The age model was finally established on the basis of a linear interpolation between ages and tie points (see Zumaque et al., 2012, for further explanations). It is important to note that supplementary stratigraphic control points, independent of climate, were retrieved from the record of the changes in the Earth's magnetic field (analysis performed at the LSCE), namely the Mono Lake and the Laschamps events. Those additional tie points give confidence in the established age model (see Fig. 4 in Zumaque et al., 2012).

The coring site experienced relatively high sedimentation rates during the last glacial period (between 23 and $408 \mathrm{~cm} \mathrm{ka}^{-1}$, with a mean around $61 \mathrm{~cm} \mathrm{ka}^{-1}$ for the studied section, i.e., $300-2090 \mathrm{~cm}$ or $\sim 12-42 \mathrm{ka}$ cal BP; see Fig. 4). These rates, combined with our sampling frequency (every $\sim 10 \mathrm{~cm}$ on the studied section for all analyses except for grain-size analyses on a short portion of the core and for magnetic susceptibility measurements, cf. Sect. 3.5.), lead to appropriate degrees of temporal resolution (between $\sim 25$ and $\sim 525$ years, with a mean of $\sim 165$ years) to study the last glacial rapid climatic variability at a sub-millennial scale. 


\subsection{Planktonic foraminifera}

Planktonic foraminifera analyses were performed on the $>150 \mu \mathrm{m}$ fraction, on the same samples as those used for dinocyst analyses. A minimum of 350 specimens per sample were counted, and 13 taxa were identified in the studied section. The dominant and major subordinate species are usually classified as surface/mid- to mid-/deep-dwelling taxa (Neogloboquadrina pachyderma (sinistral coiling), Globigerina bulloides, Turborotalita quinqueloba, $N$. incompta and Globigerinita glutinata) potentially living between 0 and $300 \mathrm{~m}$ water depths according to the literature (e.g., Schiebel et al., 2001; Table 3 in Staines-Urías et al., 2013; and references therein). Abundances of each species were calculated relative to the total sum of planktonic foraminifera. Counts of total benthic foraminifera were also performed, and planktonic and benthic foraminifera total concentrations (number of specimens per gram of dried sediment) were calculated.

Quantitative reconstructions of foraminifera-derived temperatures (hereafter "F-Temp") were obtained using a transfer function applied to planktonic foraminifera assemblages. This transfer function has been developed by Eynaud et al. (2013). It has already been described in several previous studies (e.g., Matsuzaki et al., 2011; Penaud et al., 2011; Sánchez Goñi al., 2012, 2013; Mary et al., 2015), but hereafter is a brief summary of the technical aspects of this method. The modern analogue technique (MAT; see Guiot and de Vernal, 2007, 2011a, b, for a review of this technique) was applied and performed with $\mathrm{R}$ software ( $\mathrm{R}$ version 2.7.0; http://www.r-project.org/), using the ReconstMAT script developed by J. Guiot (BIOINDIC package, https://www.eccorev.fr/spip.php?article389). The modern planktonic foraminifera database used here combines two databases previously developed within the MARGO framework (Kucera et al., 2005; Hayes et al., 2005). It includes modern assemblages and modern hydrological parameters from 1007 sites distributed over the North Atlantic Ocean and Mediterranean Sea. Modern hydrological parameters are annual and seasonal (mean winter: January-FebruaryMarch; mean spring: April-May-June; mean summer: JulyAugust-September; and mean fall: October-NovemberDecember) oceanic temperatures extracted at $10 \mathrm{~m}$ water depth (with the WOA-Sample tool created especially for the MARGO exercise, i.e., Schäfer-Neth and Manschke, 2002). Statistical treatments rely on the calculation of dissimilarity indexes between the fossil and modern spectra, leading to the selection of the five best analogues. Quantifications rely on a weighted average of temperature values associated with the five best modern analogues. For the present study, we will use the mean summer and mean winter F-Temp reconstructed with root mean square errors of prediction (RMSEP) of 1.3 and $1.2^{\circ} \mathrm{C}$, respectively.

Stable oxygen isotope measurements $\left(\delta^{18} \mathrm{O}\right)$ were also performed on monospecific samples of Neogloboquadrina pachyderma (some previously reported in Zumaque et al.,
2012, and Caulle et al., 2013, as well as new measurements). For each sample (the same as those used for F-Temp reconstructions), five to six specimens (i.e., $\sim 65 \mu \mathrm{g}$ mean weight aliquots) were hand-picked from the $200-250 \mu \mathrm{m}$ size fraction. From 300 to $1190 \mathrm{~cm}(\sim 12-27 \mathrm{ka} \mathrm{BP}, 90$ samples) measurements were done at the LSCE laboratory using a Finnigan MAT 251 mass spectrometer. The mean external reproducibility of carbonate standard NBS19 was $\pm 0.05 \%$. From 1200 to $2090 \mathrm{~cm}$ ( 27-42 ka BP, 90 samples), measurements were performed at the EPOC laboratory with an Optima Micromass mass spectrometer. Reproducibility of NBS19 was $\pm 0.03 \%$. Those two spectrometers are intercalibrated, thus allowing us to directly compare both records. In both cases, values are given versus the Vienna Pee Dee Belemnite (VPDB) standard.

To estimate past changes in seawater isotopic composition $\left(\delta^{18} \mathrm{O}_{\mathrm{SW}}\right)$, we used the paleotemperature equation developed by Epstein and Mayeda (1953) and Shackleton (1974), which links the $\delta^{18} \mathrm{O}_{\mathrm{SW}}$, the isotopic composition of calcareous shells $\left(\delta^{18} \mathrm{O}_{\mathrm{C}}\right)$ and the calcification temperature $(T)$ as follows: $T=16.9-4.38\left(\delta^{18} \mathrm{O}_{\mathrm{C}}-\delta^{18} \mathrm{O}_{\mathrm{SW}}\right)+0.13\left(\delta^{18} \mathrm{O}_{\mathrm{C}}-\right.$ $\left.\delta^{18} \mathrm{O}_{\mathrm{SW}}\right)^{2}$. Following Duplessy et al. (1991), we used $\delta^{18} \mathrm{O}$ measurements on $N$. pachyderma as $\delta^{18} \mathrm{O}_{\mathrm{C}}$, and mean summer F-Temp corrected by $2.5^{\circ} \mathrm{C}$ as $T$. We then followed the method recently described in Malaizé and Caley (2009) to extract the $\delta^{18} \mathrm{O}_{\mathrm{SW}}$ signal. Variations in this signal depend on past fluctuations of local salinities as well as on the global isotopic signal related to changes in continental ice-sheet volume. We used the global $\delta^{18} \mathrm{O}$ signal of Waelbroeck et al. (2002) to remove $\delta^{18} \mathrm{O}$ variations due to glacialinterglacial ice volume changes. We thus obtained a local $\delta^{18} \mathrm{O}_{\mathrm{SW}}$ signal that can be used as an indicator of local salinities changes in the depth range where $N$. pachyderma calcifies, i.e., from a few tens of meters to around $250 \mathrm{~m}$ water depth (e.g., Carstens et al., 1997; Simstich et al., 2003; Peck et al., 2008; Jonkers et al., 2010). Nevertheless, it should be kept in mind that this signal is not corrected from the rapid ice volume fluctuations associated with Marine Isotopic Stage 3 (MIS3) collapse events, as those fluctuations still remain not fully understood and discrepancies still exist between the various sea-level reconstructions (Siddall et al., 2008). Quantitative estimations of salinities were not carried out as large uncertainties remain concerning the temporal stability of the relation linking local $\delta^{18} \mathrm{O}_{\mathrm{SW}}$ to salinity, even if a recent study, using an atmospheric isotopic model, tends to minimize these uncertainties within our study area (Caley and Roche, 2013).

\subsection{Dinocysts}

Dinocyst-specific determination, counting, and estimates of past sea-surface estimates (through transfer function applied to dinocyst assemblages) were performed within the framework of two previous studies: Caulle et al. (2013) for the 12-27 ka BP section of the studied core and Zumaque et 
al. (2012) for the 27-42 ka BP section. Methods for palynological preparation, identification, counts, calculation of abundances, and dinocyst transfer function are described in these two studies. Data stemming from those analyses and reused in the present study are the concentration of modern (i.e., Quaternary) dinocysts (number of cysts per cubic centimeter of dried sediment), the relative abundances of some selected dinocyst species, the concentration of coenobia of freshwater micro-algae Pediastrum spp. (number per cubic centimeter of dried sediment), and quantitative reconstructions of mean summer (July-August-September) and mean winter (January-February-March) sea-surface temperatures (SST) (with RMSEP of 1.5 and $1.05^{\circ} \mathrm{C}$, respectively), mean summer and mean winter sea-surface salinities (SSS; respective RMSEP of 2.4 and 2.3 psu; see Caulle et al., 2013, and Zumaque et al., 2012, for further details).

\subsection{Ecological indices}

Some ecological indices were calculated both on dinocyst and planktonic foraminifera assemblages. Diversity is represented by the $H$ index: $-\sum_{i=1}^{s}[(n i / N) \times \ln (n i / N)]$, where $n_{i}$ is the number of specimens recorded for taxa $i, s$ the total number of taxa and $N$ the total number of individuals counted for each sample (Shannon and Weaver, 1949). Dominance corresponds to $\left(n^{\prime}+n^{\prime \prime}\right) / N$, where $n^{\prime}$ is the number of individuals of the more abundant species, $n^{\prime \prime}$ the number of individuals of the second more abundant species, and $N$ the total number of specimens counted for each sample (cf. Goodman, 1979).

\subsection{Sedimentological proxies}

Grain-size measurements were performed on a Malvern Mastersizer S at the EPOC laboratory (University of Bordeaux). Subsamples of bulk sediment were taken every $\sim 10 \mathrm{~cm}$ between 40 and $2170 \mathrm{~cm}(\sim 11-43 \mathrm{ka} \mathrm{BP})$, except between 1791.5 and $1940.5 \mathrm{~cm}(\sim 37-40 \mathrm{ka} \mathrm{BP})$, where sampling was done every centimeter (371 samples in total); those subsamples did not receive any chemical pretreatment before being analyzed. But to ensure that results obtained from non-pretreated sediment adequately reflect grain-size variations in the terrigenous fraction in our study area, a second set of analyses was conducted on carbonate-free and organic-free subsamples (pretreatment with $\mathrm{HCl} 10 \%$ and $\mathrm{H}_{2} \mathrm{O}_{2} 35 \%$ ) taken every $\sim 10 \mathrm{~cm}$ from 1593 to $1791 \mathrm{~cm}$ ( $\sim 33.6-37 \mathrm{ka} \mathrm{BP}$, same depth as the non-pretreated subsamples). Results derived from the bulk subsamples will be further represented as a mapping of the relative percentages of the different grain-size fractions along the core. Some grainsize parameters were additionally calculated: median (D50), 10th and 90th percentiles (D10 and D90), mean grain size of the $10-63 \mu \mathrm{m}$ fraction, mode, and silt ratio. The mode corresponds to the mean diameter of the most abundant size fraction. The silt ratio, reflecting size variations in the silt frac- tion, corresponds to the ratio of the percentage of the coarse silt fraction $(26-63 \mu \mathrm{m})$ over the percentage of the fine silt fraction $(10-26 \mu \mathrm{m})$.

Large lithic grain (LLG) concentrations (no. of grains per gram of dry sediment) were determined in the $>150 \mu \mathrm{m}$ sediment fraction of the studied core, in the same samples as those used for foraminifera and dinocyst analyses. As in many works conducted in the study area (e.g., Elliot et al., 1998, 2001; Rasmussen et al., 2002a; Scourse et al., 2009), we assume that LLGs contain a large proportion of IRD, and thus we consider this proxy an indicator of floating ice (i.e., icebergs or coastal sea ice) delivery to the site.

Magnetic susceptibility was measured onboard every $2 \mathrm{~cm}$ with a GEOTEK multi-sensor core logger (Labeyrie and Cortijo, 2005). More detailed magnetic analyses were performed at the LSCE with a $45 \mathrm{~mm}$ diameter MS2-C Bartington coil on the MIS 3 section (see Zumaque et al., 2012). However, as the present study also focuses on MIS 2, we chose to present the continuous onboard signal, which is furthermore very similar to the low field magnetic susceptibility record obtained at the LSCE (see Fig. 3 in Zumaque et al., 2012).

\section{Results}

As the age model and some raw data have already been shown in Zumaque et al. (2012) and Caulle et al. (2013), all data will be presented and discussed here according to a calendar BP age scale. Furthermore, those two previous studies already provided a detailed description of dinocyst assemblages and derived hydrological reconstructions. Therefore, except for the ecological indices and seasonality signals which are inherent to the present work, we will not describe these data here again.

\subsection{Micropaleontological assemblages characteristics}

Planktonic foraminifera concentrations vary from 0 to 2500 individuals $\mathrm{g}^{-1}$ dry sediment, with a mean value of around 400, and highest values recorded during GIs (Fig. 2c). Assemblages are clearly dominated by the polar taxon $N$. pachyderma (relative abundance ranging from 20 to nearly $100 \%$, Fig. 2b), peaking during GSs and HSs. G. bulloides, T. quinqueloba, N. incompta and G. glutinata are major subordinate species in some intervals, in particular GIs and the Last Glacial Maximum (LGM).

Dinocyst and foraminifera ecological indices fluctuate in phase with the abrupt climatic oscillations of the last glacial period (Fig. 2e and f). Planktonic foraminifera diversity and dominance are always negatively correlated, with low values of diversity and high values of dominance during GSs and HSs, and the opposite during GIs. Dinocysts diversity and dominance variations are mostly opposite, with generally higher values of diversity and lower values of dominance during GSs and HSs compared to GIs; they appear covariant 


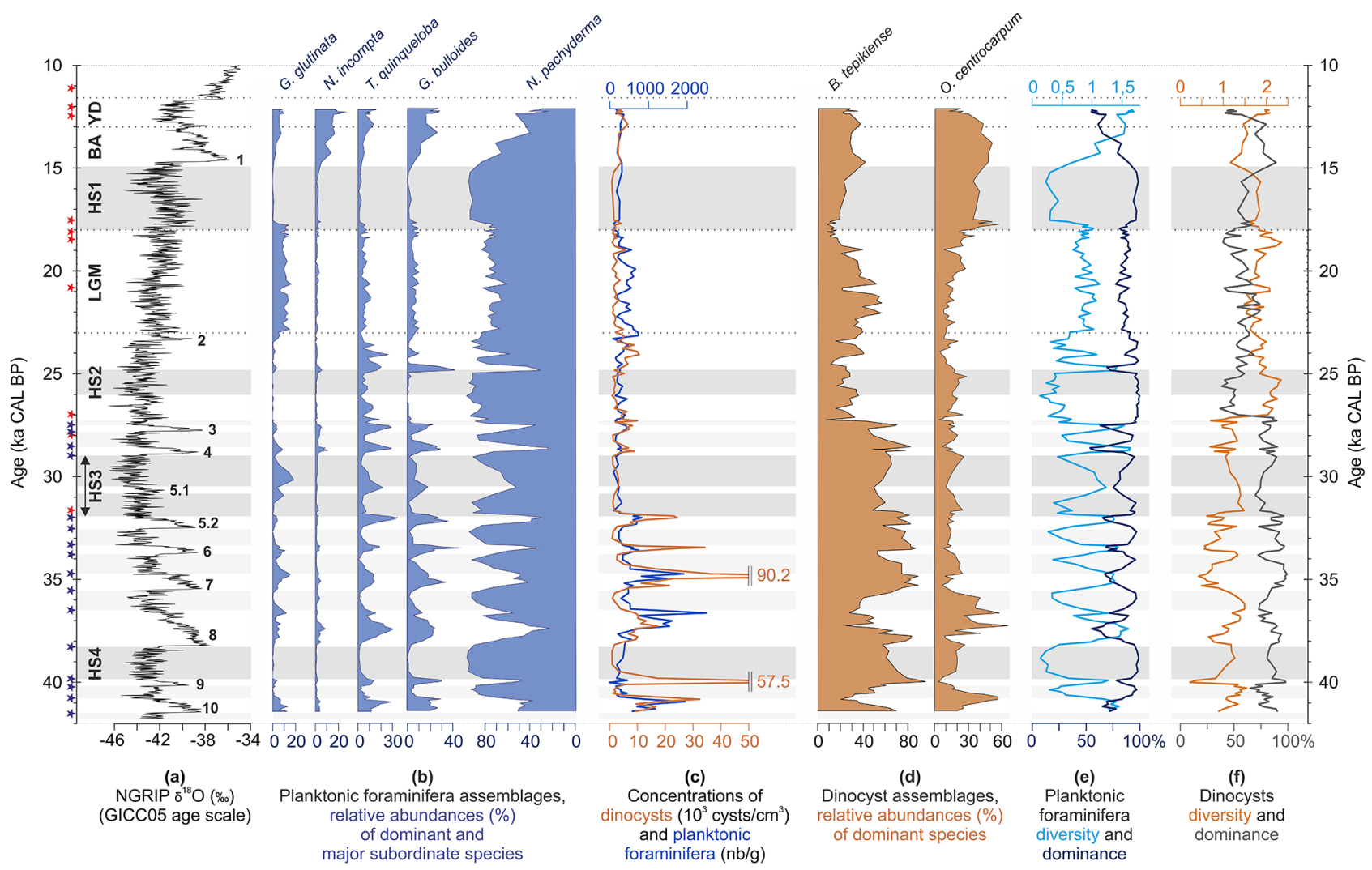

Figure 2. Evolution of index micro-planktonic assemblages compared to (a) NGRIP-GICC05 $\delta^{18} \mathrm{O}$ record: (b) relative abundances of the dominant planktonic foraminifera species, (c) absolute abundances (no. of specimen in the sediment) of dinocysts and planktonic foraminifera, (d) relative abundances of dominant dinocyst species, (e) planktonic foraminifera diversity and dominance (see calculations in Sect. 3.2.), and (f) dinocyst diversity and dominance. Red stars indicate AMS ${ }^{14} \mathrm{C}$ dates used, and blue stars show the tie points obtained by comparing the MD99-2281 magnetic susceptibility record to the NGRIP $\delta^{18}$ O signal (see Zumaque et al., 2012). GS and HS are highlighted by light- and dark-grey bands, respectively (age limits after Wolff et al., 2010). DO cycles are numbered according to corresponding GI numbers in Dansgaard et al. (1993), except for GI 5, which was divided into GI 5.2 and GI 5.1 according to Rasmussen et al. (2014). LGM stands for Last Glacial Maximum, BA for Bølling-Allerød, and YD for Younger Dryas.

only along three very short intervals during the LGM around 20.7, 21.2 and $22.9 \mathrm{ka} \mathrm{BP}$.

\subsection{Sea-surface hydrological parameters}

Planktonic foraminifera-derived mean summer temperatures (or mean summer F-Temp, Fig. 3b) vary between 2.5 and $10^{\circ} \mathrm{C}$, on average around $7^{\circ} \mathrm{C}$, and mean winter F-Temp range from -0.6 to $6.1{ }^{\circ} \mathrm{C}$ with a mean around $3^{\circ} \mathrm{C}$. These reconstructed F-Temp are lower than modern SST over the studied area, which are around 11.7 and $8.6^{\circ} \mathrm{C}$ on average for summer and winter seasons, respectively (World Ocean Atlas 2009 (WOA09) data; Locarnini et al., 2010). Despite the gap of nearly $4{ }^{\circ} \mathrm{C}$ between these two signals, they both show similar trends, with higher F-Temp during GIs and lower values during GSs and HSs (Fig. 3b).

The local $\delta^{18} \mathrm{O}_{\mathrm{SW}}$ signal derived from foraminifera (here used as an indicator of local salinity changes) also responded to the millennial-scale variability (Fig. 3g). Values vary be- tween around -2 and $1 \%$, the lowest ones being recorded during HS1 and HS4 and the highest ones during GIs, the LGM and towards the Holocene.

Seasonality signals derived from dinocysts and planktonic foraminifera (calculated as mean summer minus mean winter temperatures, Fig. 3c) are clearly different from each other. The dinocyst-derived seasonality record displays large variations, with higher values during GSs and the LGM (maximum of $15.1^{\circ} \mathrm{C}$, for an average of $13.6^{\circ} \mathrm{C}$ ) and lower ones during GIs (minimum of $5.7^{\circ} \mathrm{C}$ ). However, the foraminiferaderived seasonality signal does not exhibit any comparable variation throughout the studied period since values vary between 2.4 and $5.1^{\circ} \mathrm{C}$ with a mean value of $4.1{ }^{\circ} \mathrm{C}$.

LLG concentrations describe a general scheme rather similar to the local $\delta^{18} \mathrm{O}_{\mathrm{SW}}$ and F-Temp signals (Fig. 3). They are generally higher during GSs and HSs than during GIs. Only two noticeable exceptions exist: a high LLG concentration during the second half of GI 8, and very few LLGs during most of HS3. 


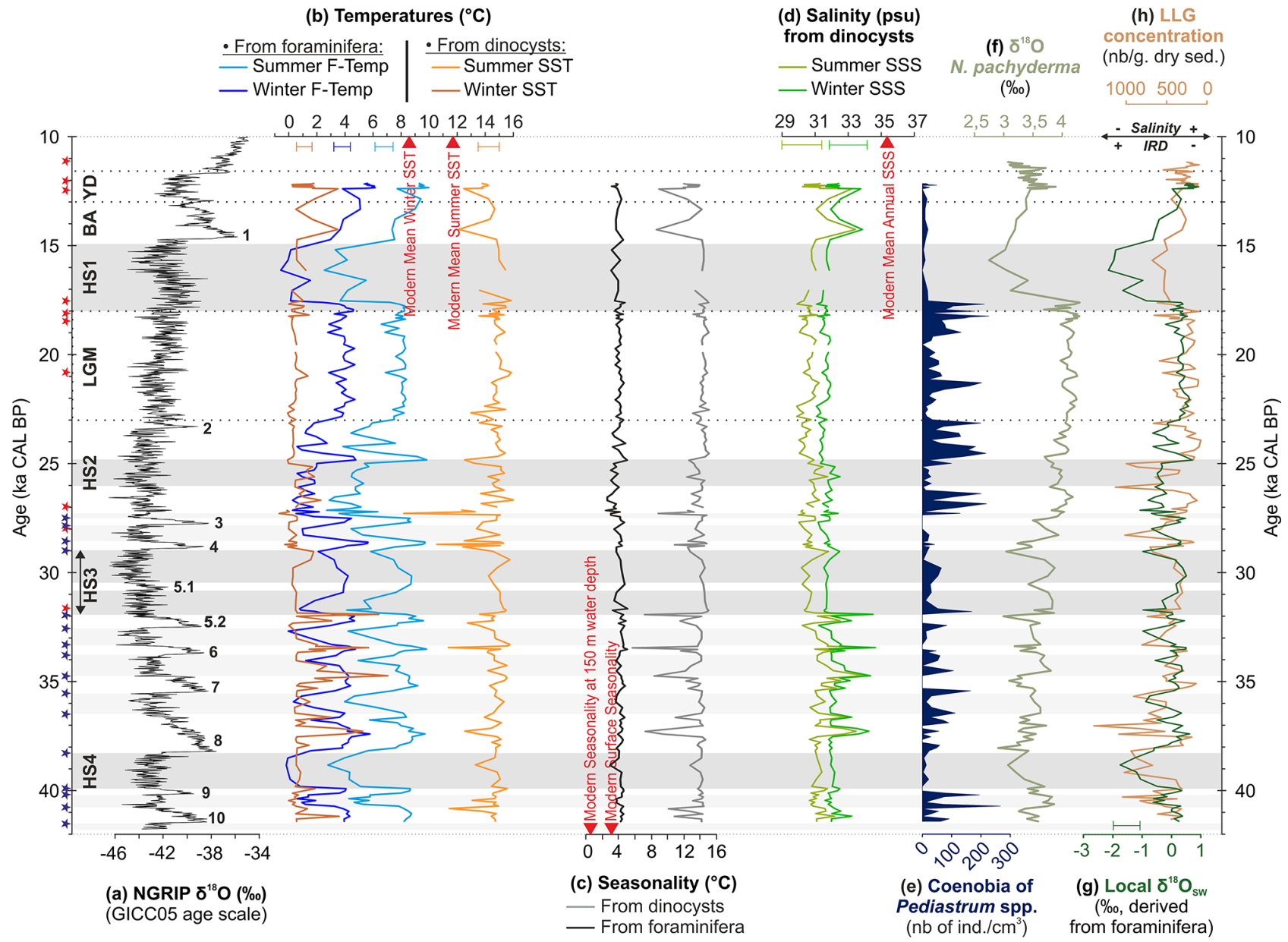

Figure 3. Reconstructed hydrological parameters derived from dinocyst and planktonic foraminifera assemblages compared to (a) NGRIPGICC05 $\delta^{18} \mathrm{O}$ record: (b) temperatures, (c) seasonality (mean summer minus mean winter temperatures), (d) SSS derived from dinocysts, (e) Abundances of coenobia of the freshwater algae Pediastrum spp., (f) $\delta^{18} \mathrm{O}$ measured on $N$. pachyderma, (g) local $\delta^{18} \mathrm{O}_{\mathrm{SW}}$ derived from $\delta^{18} \mathrm{O}$ on $N$. pachyderma, and (h) large lithic grain (LLG) concentration, plotted on a reverse scale. Stars, bands, DO number and acronyms: same legend as Fig. 2.

\subsection{Deep-water proxies}

The millennial-scale variability has also been well captured by proxies related to bottom conditions as shown in Fig. 4. Compared to stadials (i.e., GSs and HSs), GIs are characterized by higher sedimentation rates, coarser grain sizes (marked by D50 values up to $5 \phi$ and D 90 values up to $2.5 \phi$, and also evidenced on the grain-size mapping in Fig. $4 \mathrm{c}$ through the displacement towards the right, i.e., towards coarser grain sizes, of the most abundant grain-size fractions, i.e., the ones colored from light blue to red), a higher proportion of the coarse silt fraction relative to the fine silt fraction, a coarser dominant fraction, higher magnetic susceptibility values, and higher benthic foraminifera concentrations. Among stadials, only HS2 exhibits a signature comparable to that of GI. Note that, except for magnetic susceptibility (and sedimentation rate), all deep-sea proxies seem to increase gradually throughout GIs. It is visible for GI 11, 10 and 7, and particularly noticeable for GI 8; for shorter GIs, this progressive trend is hardly or not distinguishable.

\section{Discussion}

\subsection{A reworked signal?}

Considering the size of micro-organisms used in this study and the sedimentary processes occurring in the area, one could object that assemblages may not result from only local deposition but also from lateral advections including reworking of previously deposited material on proximal areas. In this case, our reconstructions would not reflect local surface and subsurface hydrology but rather a combination of allochthonous and autochthonous signals, furthermore mixed throughout time.

To identify and circumscribe these problems, we used the methodology recommended by Londeix et al. (2007) to iden- 


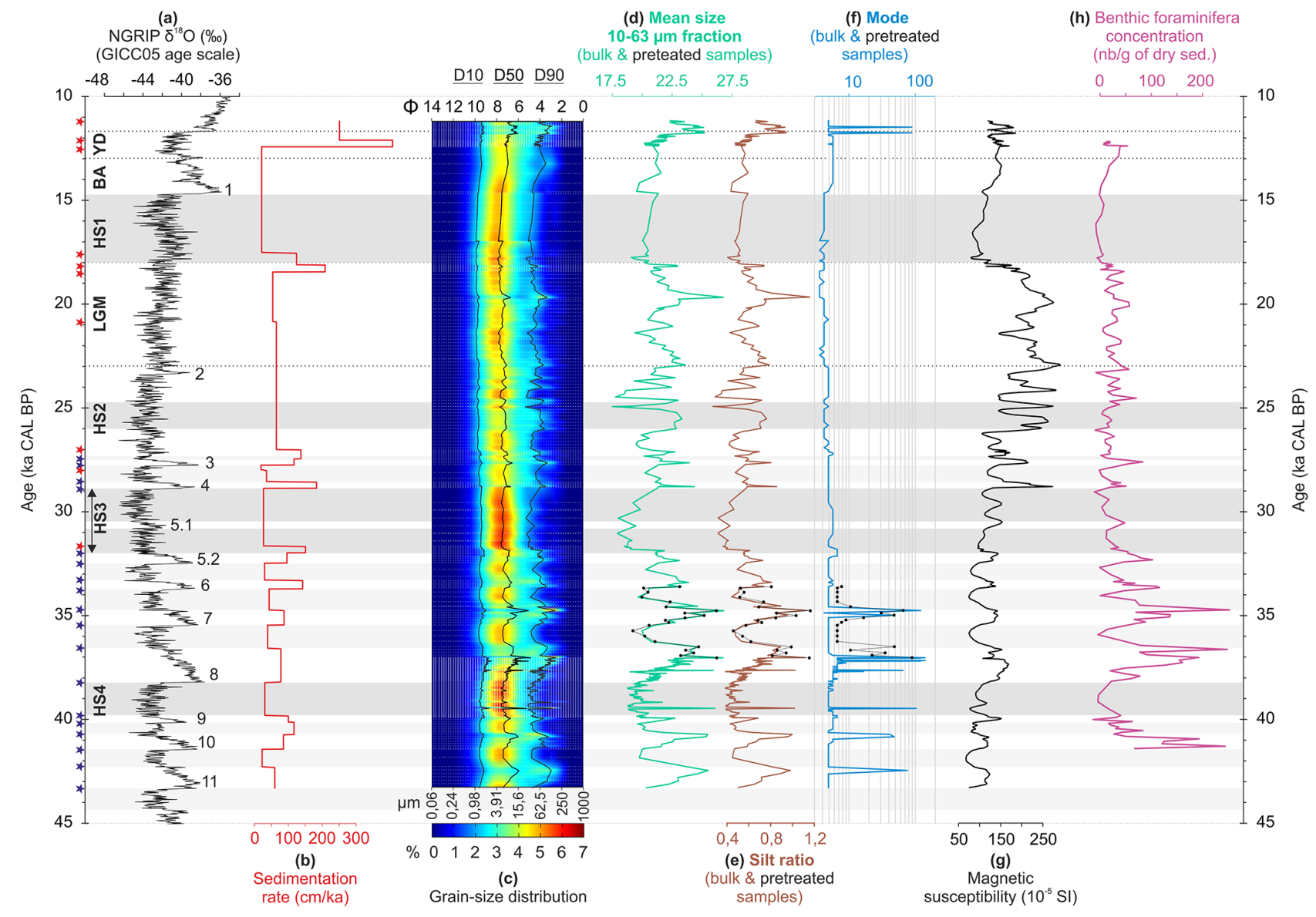

Figure 4. Evolution of oceanic bottom conditions. (a) NGRIP-GICC05 $\delta^{18} \mathrm{O}$ record, (b) sedimentation rate (calculated between two consecutive tie points), (c) grain-size distribution on the background, and D10, D50, and D90 represented as black curves in the foreground, (d) mean size of the silt $(10-63 \mu \mathrm{m})$ fraction for bulk samples and pretreated samples (carbonates and organic matter removed), (e) silt ratio between the 26-63 and 10-26 $\mu \mathrm{m}$ fractions for bulk and pretreated samples, (f) mean diameter of the dominant grain-size mode for bulk and pretreated samples, (g) magnetic susceptibility record, and (h) absolute abundances of benthic foraminifera. Stars, bands, DO number and acronyms: same legend as Fig. 2.

tify reworked intervals in sedimentary records by combining diversity and dominance indices in microfossil communities. Indeed, according to these authors, ecologically inconsistent covariance between these two indices is attributed to mixing processes. In core MD99-2281, diversity and dominance are negatively correlated all along the $12-42 \mathrm{kaBP}$ studied section regarding both planktonic foraminifera and dinocysts (except for three very short episodes during the LGM, a period not discussed in this study, and only for dinocysts, Fig. 2e and f) and therefore do not reveal any evidence of reworking.

\subsection{Interpretation of proxies}

\subsubsection{Proxies of surface and subsurface hydrology}

As shown in Fig. 3, hydrological signals derived from planktonic foraminifera (F-Temp and local $\delta^{18} \mathrm{O}_{\mathrm{SW}}$ ) and from dinocysts (SST and SSS) share common features but also dif- fer in some points through the studied period. Firstly, winter F-Temp, summer F-Temp and dinocyst-derived winter SST display similar variations and similar amplitudes of variation (with nonetheless noticeable discrepancies, e.g., during the LGM and between 32 and $27 \mathrm{ka}$ cal BP), but are clearly different from dinocyst-derived summer SST. Indeed, summer SST show a clear opposite trend to the three other reconstructed temperature signals (with higher values during GSs and HSs), and they display values well above the ones of the three other signals as well as above the modern mean ones. Secondly, at stadial-interstadial transitions, dinocyst-derived SST and SSS display gradual increases/decreases, whereas foraminifera-derived temperatures and local $\delta^{18} \mathrm{O}_{\mathrm{SW}}$ show more abrupt variations despite identical resolutions (Figs. $3 b$ and 6a). Lastly, dinocysts mainly recorded a large seasonality with significant variations over the studied period, whereas planktonic foraminifera recorded a low seasonality with very low or even no fluctuations (Fig. 3c). As has been suggested 
in previous studies (e.g., de Vernal et al., 2005, 2006; Penaud et al., 2011), such discrepancies may result from differences in depth habitat of these organisms. Indeed, dinoflagellates are restricted to the photic layer while planktonic foraminifera may live deeper. This is particularly true for the dominant and subordinate foraminifera species identified in this study, since they do not bear any symbionts. According to the literature, the depth habitat of these species potentially ranges between 0 and $300 \mathrm{~m}$ water depth (see Table 3 in Staines-Urías et al., 2013, and references therein). Moreover, dinocyst-derived SSS values are very low throughout most of the studied period (means of 31 and 32 psu for summer and winter SSS), and the main planktonic foraminifera species identified in our assemblages barely tolerate such salinities (Tolderlund and Bé, 1971). Therefore, we can reasonably consider here that dinocysts provide a record of the surface sensu stricto, whereas planktonic foraminifera recorded hydrological conditions of a larger section of the upper water column that we hereafter refer to as the subsurface for simplicity. It is worth noting that F-Temp reconstructions cannot be considered subsurface absolute reconstructions since temperatures in the modern database used for the transfer function are extracted at $10 \mathrm{~m}$ water depth. However, interpreting them as subsurface relative estimations is coherent if we consider previous works focused on transfer functions applied to planktonic foraminifera assemblages (see Supplement).

Seasonality values derived from dinocysts (averaged value over the studied period of $\sim 13.6^{\circ} \mathrm{C}$, Fig. 3c) are $\sim 4$ times higher than the modern sea-surface seasonality value over the study area $\left(\sim 3.2^{\circ} \mathrm{C}\right.$; calculated from WOA09 data as mean summer minus mean winter oceanic temperatures; Locarnini et al., 2010). It might seem surprising, but similar values are presently recorded in several areas around the world (at the outlet of the Gulf of St Lawrence, in the Baltic Sea and outlets of the bordering gulfs, in the Sea of Japan, the East China Sea, the Black Sea, and the Caspian Sea, according to WOA09 data; Locarnini et al., 2010). For some of these areas, such high seasonality contrasts are related to a stratification of the upper water column marked by the presence of a halocline (e.g., the Baltic Sea: Kullenberg, 1981; the outlet of the Gulf of St Lawrence: Banks, 1966). Indeed, the very low SSS values recorded by dinocysts (which are well below the modern ones over the study area, equal to 35.3 psu according to WOA09 data; Antonov et al., 2010; Fig. 3d), as well as the presence of the freshwater micro-algae Pediastrum spp. (a marker of freshwater advection in surface; e.g., Eynaud et al., 2007), support the existence of a thin freshwater surface layer of low thermal inertia overlying the study area during most of the studied period. Similar to present situations, this freshwater layer would have certainly been responsible for a strong stratification of the water column due to the presence of a halocline. Such a pattern is also qualitatively consistent since the most abundant dinocyst species is Bitectatodinium tepikiense, a taxon which displays a strong affinity for stratified surface waters characterized by a large seasonality (Rochon et al., 1999). Furthermore, this interpretation explains why dinocyst (i.e., surface) signals are noisier than planktonic foraminifera ones.

Iceberg calving and associated meltwater inputs are potential initiator and feeder of this halocline. IRD content has mainly been used as a tracer for these iceberg surges. Here, we use LLG concentrations and assume, as generally admitted, that LLGs are mainly constituted of IRD. Our LLG signal is indeed very similar to IRD records coming from many studies and sites in North Atlantic (e.g., Bond and Lotti, 1995; Elliot et al., 1998, 2001; Van Kreveld et al., 2000; Rasmussen and Thomsen, 2004; Dickson et al., 2008) which described higher IRD concentrations during GSs and HSs and variable concentrations during the LGM. This supports the assumption that our LLG signal can be used as an indicator of iceberg delivery to the studied site. In this case, the resemblance between LLG concentrations and local $\delta^{18} \mathrm{O}_{\mathrm{SW}}$ and subsurface temperature (F-Temp) signals suggests that these latter signals are at least partly forced by iceberg calving and melting and associated cold freshwater releases. However, variations in the warm and salty northward Atlantic flow could also play a major role in the fluctuations of these signals. Many freshwater model experiments (e.g., Manabe and Stouffer, 1995; Ganopolski and Rahmstorf, 2001; Levine and Bigg, 2008) have indeed shown that these two processes are clearly linked, in the sense that (i) freshwater release weakens the Atlantic meridional overturning circulation and limits the northward extension of the NAD, and (ii) the larger the amount of released freshwater is, the weaker the oceanic circulation. Moreover, the correspondence between LLG and foraminifera-derived signals is only partial. Some delays (e.g., during HS4, GS8, GS6) and incoherencies (e.g., the relatively long periods before and after HS2 with considerably low $\delta^{18} \mathrm{O}_{\text {Sw }}$ but almost no LLG) can indeed be noticed. This leads us to think that paleo-fluctuations of our foraminiferaderived signals are the result of the combined two phenomena: the warm and saline Atlantic water northward flow and its southward retreat, and the episodic cold and fresh water release associated with iceberg surges. Respective contributions of these two phenomena could seem difficult to dissociate, but in this study, dinocyst data provide valuable clues. Indeed, as mentioned above, dinocyst-derived SSS and seasonality signals are indicators of surface stratification. Thus we can suppose that, during periods of high surface stratification (i.e., periods when the halocline strongly hampers or even prevents mixing between surface and subsurface waters), variations in F-Temp and local $\delta^{18} \mathrm{O}_{\mathrm{SW}}$ should be principally due to variations in the NAD intensity. Conversely, during periods of weaker surface stratification, and when iceberg calving occurred, variations in planktonic foraminiferaderived parameters should be the result of the combination of meltwater inputs from the surface and NAD variations; however, during periods of low stratification and without iceberg calving, subsurface hydrological variations should be due to NAD fluctuations only. 

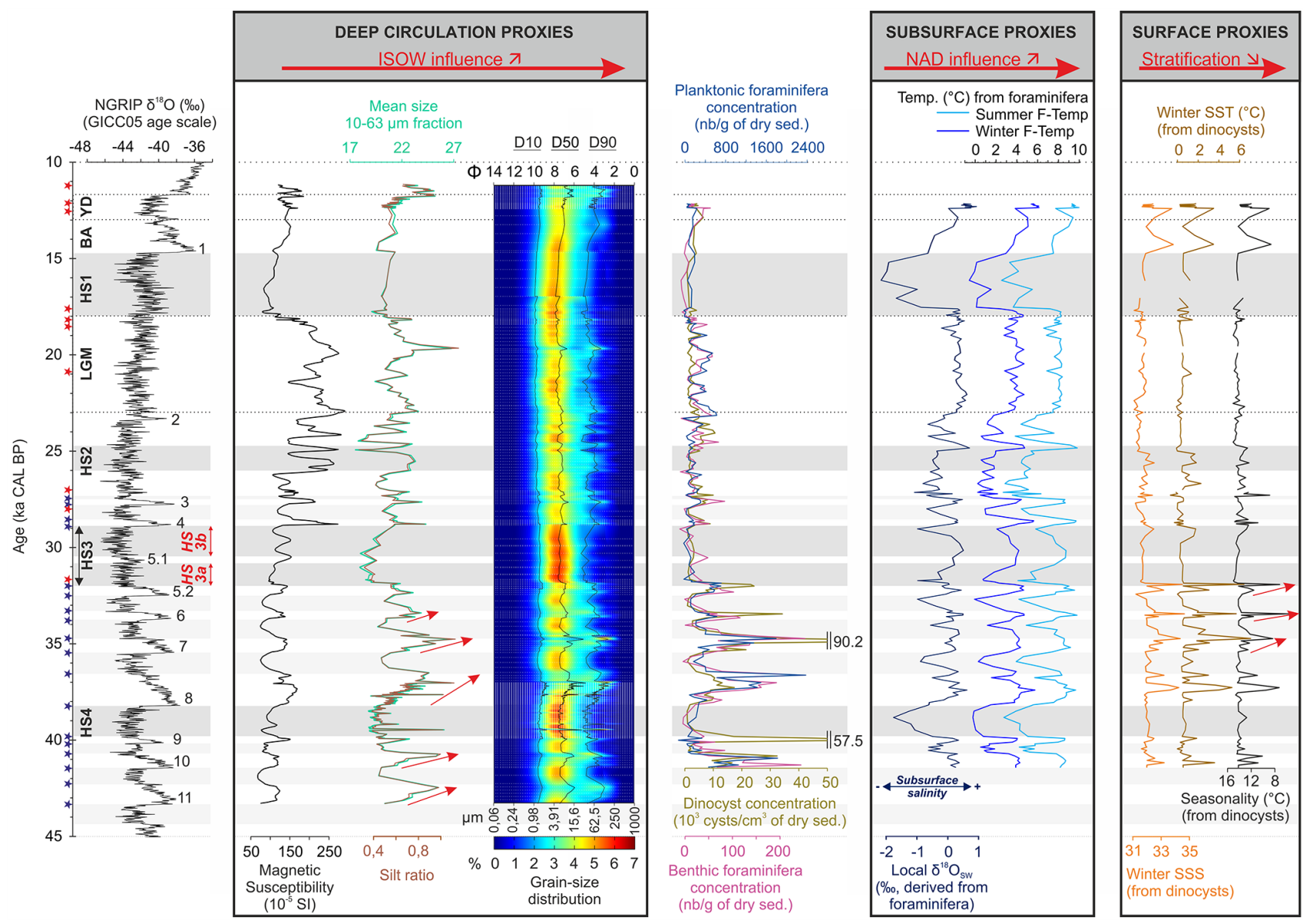

Figure 5. Comparative figure showing the evolution through time of proxies indicative of the ISOW bottom dynamics (left framed panel), the subsurface NAD intensity (middle framed panel), and the surface sensu stricto conditions (right framed panel). Absolute abundances of benthic foraminifera, planktonic foraminifera, and dinocysts are shown in the middle unframed panel. NGRIP $\delta^{18} \mathrm{O}$ record is shown at the far left to illustrate the chronological framework. Stars, bands, DO number and acronyms: same legend as Fig. 2. Red arrows highlight the progressive trends.

\subsubsection{Proxies of deep-water currents}

Reconstructing past variations in the ISOW dynamics deserves to be attempted in this study as our multi-proxy approach provides various indicators of bottom current activities (Fig. 4). The first type of bottom flow proxy corresponds to parameters derived from grain-size measurements. These parameters (listed in Sect. 3.5 and below) have been widely employed in reconstructions of bottom current activity (e.g., McCave et al., 1995a, b; McCave, 2007; Bianchi and McCave, 1999; Hodell et al., 2009). Their use is based on the fact that bottom currents preferentially affect the silt fraction $(10-63 \mu \mathrm{m})$ by size sorting in such a way that stronger currents induce a coarsening and an increase in the relative proportion of this size fraction. Basically, an intensification of the ISOW will be depicted as a coarsening of D10, D50, and D90 (Fig. 4c), an increase in the mean size of the 10-63 $\mu \mathrm{m}$ fraction (Fig. 4d) and of the silt ratio (Fig. 4e), a coarsening of the dominant mode towards values corresponding to the silt fraction or even coarser (Fig. 4f), and a grain-size distribution showing a coarsening and an increase in the relative proportion of this coarse fraction (Fig. 4c). It is important to note that, in the glacial North Atlantic Ocean, IRD $<150 \mu \mathrm{m}$ could constitute a potential source of silt-size particulates which could bias the use of these parameters as bottom flow proxies (Prins et al., 2002). Nevertheless, in our case, LLG concentrations are generally higher during GSs, i.e., when grain-size distribution and parameters indicate a general finning of the total sediment fraction - including silt fraction - and a predominance of the $<10 \mu \mathrm{m}$ fraction. As the supplies of IRD $>150 \mu \mathrm{m}$ (i.e., LLG) and $<150 \mu \mathrm{m}$ are supposed to be synchronous, the impact of IRD inputs (fine as well as coarse ones) on the grain-size distribution seems to be minor, and so do not seem to bias the use of grain-size parameters as indicators of the bottom current strength. In a similar way, biogenic inputs could also influence grain-size distribution and bias the grain-size proxies. However, Fig. 4d, e and $\mathrm{f}$ show that the calculated grain-size parameters for the bulk 
samples and for the pretreated ones exhibit the same variations in terms of timing as well as in amplitude. Furthermore, grain-size analyses on pretreated samples were conducted on the core section where the content of $\mathrm{CaCO}_{3}$ (data not shown) displays the largest variations and attains its maximal value over the studied portion of the core. This confirms that, in our study area, grain-size variations in bulk sediment almost exclusively reflect changes in the terrigenous fraction and thus can be directly interpreted in terms of fluctuations of the bottom current intensity.

The second type of bottom flow proxy used in this study is the magnetic susceptibility (Fig. 4g). Kissel et al. (1999, 2009) have shown that, in areas distributed along the path of the deep-water masses feeding the North Atlantic Deep Water, magnetic susceptibility fluctuations are directly related to variations in the relative amount of magnetic particulates within the sediment; as those magnetic minerals principally originate from a unique source (the Nordic basaltic province), changes in magnetic susceptibility reflect changes in the efficiency of their transport mode from the source area to the study site, i.e., changes in the intensity of bottom currents. Hence, in our study area, higher values of magnetic susceptibility reflect higher ISOW energy.

Our last type of indicator of bottom flow activity corresponds to benthic foraminiferal concentrations (Fig. 4h). Indeed, in the study of different cores located in the study area, Rasmussen et al. (1997, 1999, 2002a) related this parameter to the activity of the ISOW, with high concentrations of benthic foraminifera associated with relatively strong bottom current influence and increased ventilation and supply of food, and conversely low benthic abundances related to more quiet deep-sea conditions with reduced fluxes of organic matter.

When looking at the evolution of all these proxies in core MD99-2281, it clearly appears that they all tend toward the same general scheme: the ISOW was relatively active during GIs and relatively reduced during GSs (Figs. 4 and 5). These results are in accordance with findings from previous studies (e.g., Moros et al., 1997, 2002; Van Kreveld et al., 2000; Elliot et al., 2002; Rasmussen and Thomsen, 2004; Ballini et al., 2006). Furthermore, the higher sedimentation rates recorded during GIs (Fig. 4b) indicate that, in our study area and during the studied period, the ISOW was responsible for a higher accumulation of sediment during episodes of high activity rather than for a winnowing of the clay fraction $(<10 \mu \mathrm{m})$.

Since the age model of the studied core is based on correlations between our magnetic susceptibility record and the $\delta^{18} \mathrm{O}$ signal of NGRIP ice core (i.e., on the assumption that the ISOW was reduced during GSs), one could argue that we cannot make any supposition about the timing of changes in deep current intensity. This would be obviously true in the case of studies intending to precisely compare the timing of these changes relative to the timing of Greenland atmospheric variations. But this is not the case of our study, which aims to compare the timing of deep circulation changes with that of surface and subsurface hydrological variations (as deduced from the same sedimentological archive), and to compare the trends of all those fluctuations (progressive vs. abrupt).

\subsection{Hydrological signature during Dansgaard-Oeschger events and implications}

MD99-2281 records are in general agreement with the usual climatic scheme depicted in previous studies and described in the introduction of this paper, i.e., iceberg surges and a weaker Atlantic meridional overturning circulation during GSs, and conversely warmer surface conditions linked to a more northerly inflow of Atlantic surface waters and associated active deep-water convection in the Nordic Seas during GIs (cf. Fig. 5). This is especially noticeable with the strong and striking correlation between dinocysts, planktonic and benthic foraminifera abundances throughout all the studied period, which furthermore suggests a coupling of the productivity at the different layers of the water column.

However, our records also reveal unusual features, such as the strong stratification of surface waters during GSs. Previous studies from the subpolar North Atlantic (e.g., Rasmussen et al., 1996a, b; Rasmussen and Thomsen, 2004; and Dokken et al., 2013, at study sites close to MD99-2281 site, and Van Kreveld et al., 2000, in the Irminger Basin) already indirectly deduced from planktonic foraminifera data the presence of a halocline and a stratified water column during GSs. In our study, dinocyst assemblages and dinocystderived surface hydrological parameters provide direct evidence of the presence of a thin freshwater surface layer and stratified surface waters during stadials, therefore confirming the previous assumption based on indirect proxies (rather subsurface proxies).

Our records also show atypical progressive trends that can be depicted within GSs and most of all within GIs (Figs. 3, 5 and 6a). During GSs, dinocyst data indicate a deterioration of surface conditions characterized by a more or less gradual decrease in winter SST (depending on the GS considered), while summer SST, surface stratification and seasonality remain high. Foraminifera-derived subsurface hydrological parameters and grain-size data show rapid transitions at the beginning of GSs (especially noticeable for GS 10 and 8, for example) which denote an abrupt slowing down of the northward Atlantic flow (sharp decreases in F-Temp and local $\delta^{18} \mathrm{O}_{\mathrm{SW}}$ ) and of the deep ISOW (marked decreases in grain sizes, silt ratio and mean size of the silt fraction) at those times. Throughout GIs, dinocyst data reveal progressively milder surface conditions marked by a gradual increase in winter SST in parallel with a gradual decrease in stratification and seasonality. Grain-size data also indicate a gradual intensification of the ISOW flow, with a maximal intensity at the end of these periods (particularly noticeable when looking at the silt ratio and the mean size of the $10-63 \mu \mathrm{m}$ frac- 


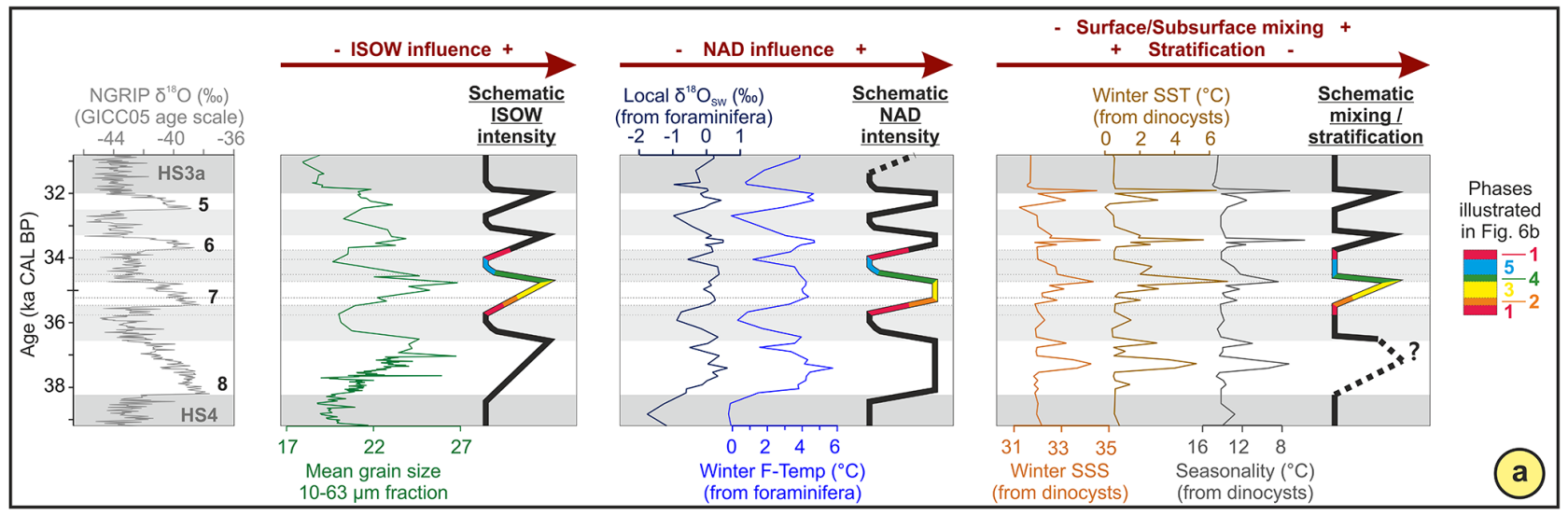

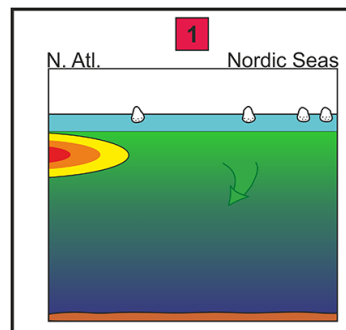

Very end of GSs:

NAD rapidly re-intensifies, but the water column is still highly stratified. The halocline prevents any heat exchange towards the atmosphere. Subsurface waters get warmer and warmer. Deep convection is nil or limited.

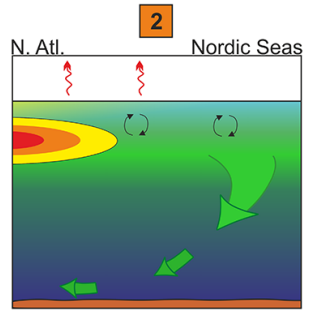

Beginning of Gls:

The halocline starts to be unstable; surface and subsurface waters start to ix, and stratification Discreet heat exchange towards the atmosphere occurs. Deep convection is progressively reactivated.

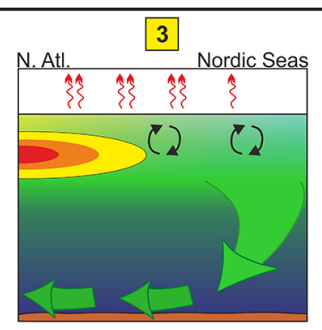

Middle + end of GIs:

The NAD activity is maximal. Subsurface waters progressively mixed with surface waters throughout $\mathrm{G}$ intervals. Heat is released to the atmosphere. Deep convection is fully convection is fully
reactivated; the ISOW vigor increases throughout $G$ intervals and reaches its maxima at the end of Gls.

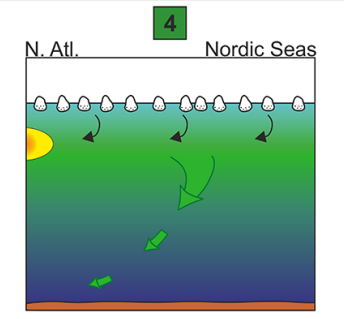

Beginning of GSs:

Iceberg discharges occur. The associated meltwate inputs propagate in the mixed surface/subsurface layer, lower its salinity, increase the degree of increase the degree of
stratification, reduce deep stratification, reduce deep
convection, and weaken the NAD and ISOW flows.

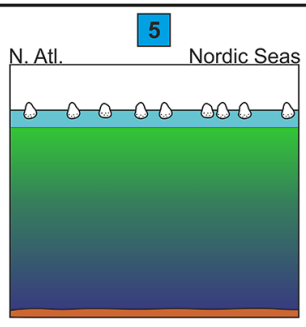

Middle of GSs:

Surface waters are highly stratified. NAD and ISOW flows are nonexistent or
weak.

Figure 6. Synthetic figure illustrating the hydrological processes occurring during Dansgaard-Oeschger cycles at the study site. (a) Closeups of DO 8, 7, 6 and 5 showing the evolution of some selected proxies shown in Fig. 5, as well as the schematic evolution through DO cycles of the ISOW activity, the NAD vigor, the intensity of mixing between surface and subsurface waters, and the degree of surface stratification. (b) Conceptual representation of the hydrological processes occurring during the different phases of DO cycles as depicted in Fig. 6a.

tion, and highlighted by red arrows in Fig. 5). Conversely, planktonic foraminifera data show that the subsurface reactivation of the NAD at GS-GI transitions was more abrupt than shown within proxies of surface and deep-sea dynamics.

At first sight, our set of proxies thus denotes a decoupling between surface, subsurface, and deep-sea hydrological processes during DO cycles. This is in agreement with previous studies which suggested a decoupling between surface and subsurface (Moros et al., 2002) or subsurface and deep circulations (Rasmussen et al., 1996b). However, a detailed examination of our records reveals that subsurface and deep circulations are coupled during GSs, i.e., when surface waters are highly stratified, and that surface and deep circulations are coupled during GIs, i.e., when the stratification is reduced. This leads us to think that the surface stratification is a determinant factor for hydrological processes occurring at greater depth around the study area. We can therefore propose the following scenario, which conciliates our records and highlights the importance of the water-column organization during millennial scale climatic events (Fig. 6b).

At the end of GSs, the NAD rapidly extends northward again. However, the water column is still highly stratified and the near-surface halocline prevents heat exchange towards the atmosphere; heat is thus stored in the subsurface layer below the halocline. Subsurface waters are consequently not dense enough because they are too warm to sink and deep convection is zero or very limited (at least north of our study site). Then, at the beginning of GIs, the halocline starts to be unstable (probably because of the accumulation of heat below). The stratification is then progressively reduced, and heat exchange (between subsurface and surface, and surface and atmosphere) becomes possible again. Subsurface Atlantic waters progressively mix with low-salinity surface waters, which become progressively saltier. They become sufficiently dense to sink, and deep convection is thus reactivated and progressively intensifies throughout GIs. As a consequence, the ISOW activity progressively strength- 
ens and reaches its maximal vigor at the end of this period. Then, at the beginning of GSs, iceberg discharges occur. The associated meltwater has several consequences on the stadial hydrology. First, the freshwater input rapidly propagates in the mixed surface-subsurface layer, lowers its salinity, and strongly reduces deep convection, thus weakening the NAD and the ISOW flows. Secondly, it contributes to the reestablishment of the freshwater surface layer and the associated halocline, as well as to the progressive slight strengthening of the stratification. NAD and ISOW flows remain weak until the end of GSs.

Rasmussen et al. (1996a, b) and Rasmussen and Thomsen (2004) proposed a similar scenario where an accumulation of heat below the fresh surface layer is responsible for the destabilization of the halocline and the abrupt release of a large amount of heat to the atmosphere, thus causing the sudden Greenland atmospheric warming. On the basis of benthic assemblages from various cores located around the Faeroe Islands (e.g., ENAM93-21: 62.7383 ${ }^{\circ} \mathrm{N}, 3.9987^{\circ} \mathrm{W} ; 1020 \mathrm{~m}$ water depth - ENAM33: $61.2647^{\circ} \mathrm{N}, 11.1609^{\circ} \mathrm{W} ; 1217 \mathrm{~m}$ water depth), they suggested that relatively warm Atlantic intermediate waters keep on flowing into the Nordic Seas below the halocline during GSs, and they attributed these warm Atlantic waters to the NAD. However, our results derived from planktonic foraminifera data do not indicate any significant flow of NAD directly below the halocline during GSs (Rasmussen et al., 1996a, b, and Rasmussen and Thomsen, 2004, recorded indeed a total dominance of Neogloboquadrina pachyderma during stadials) but they do enable such a flow at deeper water depth. In this case, both the reactivation of the subsurface NAD at the end of GSs and the continuous northward flow of Atlantic intermediate waters during GSs may have participated in the accumulation of heat below the halocline, the destabilization of the latter, and then the sudden release of heat to the atmosphere at GS-GI transitions.

Dokken et al. (2013) also proposed a similar scenario for GSs, with a fresh surface layer, a halocline, and an active Atlantic inflow just below it. This scenario was inferred from planktonic foraminifera data in core MD99-2284 $\left(62.3747^{\circ} \mathrm{N}, 0.9802^{\circ} \mathrm{W} ; 1500 \mathrm{~m}\right.$ water depth). Considering the location of their study site close to the continental shelf edge, this shallow Atlantic inflow is not in contradiction to our results, which allow the presence of a narrow warm Atlantic inflow flattened against the shelf edge by the Coriolis force. Such a narrow flow would not be recorded in cores located further away from the shelf such as ours.

The observed gradual intensification of the ISOW flow during GIs constitutes the most unusual and salient feature revealed by our data. However, a previous study from the Reykjanes Ridge (Snowball and Moros, 2003) also depicted a very similar pattern in magnetic susceptibility data and quartz to plagioclase ratio in cores LO09-18GC $\left(58.9674^{\circ} \mathrm{N}, 30.6832^{\circ} \mathrm{W} ; 1460 \mathrm{~m}\right.$ water depth) and SO82$05 \mathrm{GGC}\left(59.1857^{\circ} \mathrm{N}, 30.9047^{\circ} \mathrm{W} ; 1420 \mathrm{~m}\right.$ water depth), with a progressive intensification of the ISOW during GIs followed by an abrupt reduction.

\subsection{Different hydrological patterns during Heinrich stadials}

Figure 5 clearly shows that the four HSs recorded in the studied section of core MD99-2281 (HS1, HS2, HS3 (which can be divided into HS3a and HS3b; see below) and HS4) do not exhibit the same hydrological patterns. The only common feature corresponds to the harsh surface conditions deduced from dinocyst data and also depicted during GSs, and characterized by the presence of a fresh water lid, a high seasonality and a relatively strong stratification of the water column. However, planktonic foraminifera data and deep-sea proxies show different signals, in amplitude or in trend, thus suggesting different subsurface and deep-water mass dynamics (see Table 1).

HS1 and HS4 seem to be characterized by the usual features associated with HSs in the literature, i.e., with very low local $\delta^{18} \mathrm{O}_{\mathrm{SW}}$ values indicative of very low salinities in the subsurface layer, and strongly reduced or even shut down northward Atlantic flow and deep-water overflow (according to foraminifera-derived data and grain-size data, respectively). Compared to GSs, our data indicate a more drastic reduction of the meridional overturning circulation and a more southerly location of the deep convection center during HS1 and HS4, in agreement with previous studies (e.g., Elliot et al., 2002; Rahmstorf, 2002).

In contrast, HS2 presents a very atypical hydrological signature: grain-size data, in agreement with the magnetic susceptibility signal, indicate a relatively active ISOW; in parallel, subsurface records show F-Temp and local $\delta^{18} \mathrm{O}_{\mathrm{SW}}$ comparable to most GS ones but higher than those of the "classical" HS1 and HS4 and even of some GSs. These results indicate the presence of saltier (and thus denser) and slightly warmer subsurface waters bathing our study site, and thus denotes a slightly more active meridional overturning circulation and a more northerly center of convection during HS2 compared to "classical" HSs. This would in any case be in agreement with previous paleoreconstructions: in core $\mathrm{Na} 87-22$ (located on the eastern banks of the Rockall Plateau: $55.4833^{\circ} \mathrm{N}, 14.6833^{\circ} \mathrm{W} ; 2161 \mathrm{~m}$ water depth), Elliot et al. (2002) found benthic $\delta^{13} \mathrm{C}$ values during HS2 which are higher than HS1 and HS4 values and similar to GS values; according to the interpretation of this proxy made by the authors, this suggests that the reduction of deep-water formation and the northward migration of $\delta^{13} \mathrm{C}$-depleted southern source deep waters were less important during HS2 and stadials than during HS1 and HS4. Much farther away from our study area, in the Gulf of Cadiz, core MD99-2339 $\left(35.88^{\circ} \mathrm{N}, 7.53^{\circ} \mathrm{W} ; 1170 \mathrm{~m}\right.$ water depth; Voelker et al., 2006) also provides indirect evidence of a more active North Atlantic overturning circulation. Indeed, paleoreconstructions of the strength of the Mediterranean 
Table 1. Synthesis of the main hydrologic features depicted at the study site during Heinrich stadials (HS) 1 to 4.

\begin{tabular}{|c|c|c|c|c|}
\hline Event & Bottom (ISOW) & Subsurface (NAD) & Surface & Interpretations \\
\hline HS1 \& HS4 & Weak or stopped & Weak or stopped & \multirow{3}{*}{$\begin{array}{l}\text { High stratification- } \\
\text { no mixing between } \\
\text { surface and subsur- } \\
\text { face waters }\end{array}$} & HS as usually described \\
\hline HS2 & Relatively active & $\begin{array}{l}\text { More active than during } \\
\text { HS1 \& HS4 }\end{array}$ & & $\begin{array}{l}\text { "Atypical" HS (relatively active over- } \\
\text { turning circulation, center of deep con- } \\
\text { vection located more northerly) }\end{array}$ \\
\hline HS3 & Three-phased or weak & Three-phased $(\downarrow \uparrow \downarrow)$ & & $\begin{array}{l}\text { Three-phased event (HS3a, GI 5.1, } \\
\text { HS3b) }\end{array}$ \\
\hline
\end{tabular}

Outflow Water (or MOW, which overflows from the Mediterranean Sea to and within the Gulf of Cadiz) have shown that this bottom current has been particularly active during periods of weak Atlantic meridional overturning circulation such as GSs and HSs (e.g., Cacho et al., 2000; Voelker et al., 2006; Toucanne et al., 2007). Grain-size data of core MD99-2339 show indeed a clear intensification of the MOW during HS1, HS4, HS5, and most GSs. However, they do not indicate such a strengthening during HS2 (and HS3) and therefore could denote a more vigorous North Atlantic circulation. Furthermore, Scourse et al. (2009) evidenced higher IRD fluxes during HS2 (compared to the other HSs) in cores located west and north of Great Britain. According to the authors, these strong fluxes typify the maximal extent of the British-Irish Ice Sheet. In such a context, an Atlantic flow extending more northerly as compared to the other HSs might have also contributed to enhancement of iceberg release from the BritishIrish Ice Sheet.

Concerning HS3 (usually defined as the interval starting at the end of GI 5 and ending at the start of GI 4), grain-size data tend to indicate a low ISOW activity throughout the interval. However, foraminifera-derived subsurface parameters show a tripartite structure with (i) low F-Temp and local $\delta^{18} \mathrm{O}_{\mathrm{SW}}$ values indicative of a weak NAD at the beginning and the end of the event and (ii) higher values pointing to a stronger NAD in the central part of the event. Moreover, the magnetic susceptibility record shows two peaks around 29.5 and $30.5 \mathrm{ka} \mathrm{BP}$ coeval with high F-Temp and local $\delta^{18} \mathrm{O}_{\mathrm{SW}}$ values. Benthic foraminifera concentrations also display a peak concomitant with the first magnetic susceptibility peak. Furthermore, Elliot et al. (2002) found a two-phased incursion of southern sourced waters (at the onset and the termination of the event) in core $\mathrm{Na} 87-22$ from the Rockall Plateau and core SU90-24 from the Irminger Basin $\left(62.0667^{\circ} \mathrm{N}, 37.0333^{\circ} \mathrm{W}\right.$; $2100 \mathrm{~m}$ water depth). Hence, all of these records suggest that HS3 might have been a three-phased event with classical disruptions of the overturning circulation at the beginning and the end of the event, interrupted by a significant resumption of this circulation. The beginning of the period of resumption of this circulation is concomitant with the short interstadial phase defined as GI 5.1 by Rasmussen et al. (2014). Since both intervals before and after GI 5.1 have previously been related to HS3 (e.g., Sánchez Goñi and Harrison, 2010; Hall et al., 2011) we propose to follow Rasmussen et al. (2014) and to divide the usual HS3 period into three phases: HS3a, GI 5.1, and HS3b such as indicated in Fig. 5. In this way, HS3a and HS3b can be considered two periods of relatively weak Atlantic meridional overturning circulation, separated from each other by a phase of re-intensification of this circulation that is also detectable in Greenland ice core records as a milder phase (GI 5.1). The absence of clear evidence of ISOW reactivation in grain-size data during GI 5.1, and its discrete and arguable evidence in the magnetic susceptibility and benthic concentration records, is puzzling if we consider, as advanced previously, that subsurface and deep circulations should be coupled due to the strong surface stratification. However, the Wyville Thompson Ridge could have acted as a topographic barrier (even more than at present) that would have prevented a too weak deep flow to influence our study site by constraining it into the Faeroe Bank Channel (cf. Fig. 1).

\section{Conclusion}

Analyses carried out within the framework of this study confirm that the area southwest of the Faeroe Islands has been very sensitive to the last glacial millennial-scale climatic variability. Our multiproxy approach allows us to track hydrological processes at different key water depths, and reveals a partly and episodically coupling of surface, subsurface and deep-water mass dynamics controlled by surface stratification during rapid climatic shifts. Indeed, GIs are characterized by a decreasing stratification and a coupling of surface and deep hydrological processes, with progressively milder surface conditions and gradual intensification of the ISOW, while the activity of the subsurface NAD flow remains constantly high. Conversely, GSs experienced a high surface stratification and coupled subsurface and deep circulations marked by a sharp weakening of the NAD and the ISOW at the beginning of GSs, while surface conditions progressively deteriorate throughout GSs. These results led us to propose a scenario describing the evolution and interactions of hydrological processes during DO cycles and taking into account the determining role of the surface stratification. Our records 
also denote different hydrological signatures during Heinrich stadials. HS1 and HS4 appear as "classical" HS with strongly reduced Atlantic meridional overturning circulation. In contrast, HS2 probably experienced a relatively active North Atlantic circulation. Finally, HS3 seems to be a three-phased event marked by a re-intensification of the overturning circulation in the middle of the event.

Our study highlights the importance of coupling nearsurface reconstructions of oceanic conditions to avoid misinterpretation of data, particularly in areas affected by changes in the structure of the upper water column. It illustrates the potential of such high-resolution multi-proxy paleoreconstructions, especially in areas close to glacial ice sheets when aiming to track hydrological processes occurring during the still so enigmatic rapid climatic oscillations of glacial periods. It also encourages model experiments to take into account stratification artifacts and 3-D oceanic scenarios, and to test the robustness of the hydrological mechanisms and interactions proposed in this work.

\section{The Supplement related to this article is available online at doi:10.5194/cp-11-1507-2015-supplement.}

Acknowledgements. Part of the analyses conducted on MD992281 was supported by the French INSU (Institut National des Sciences de l'Univers) program LEFE (Les enveloppes fluides et l'environnement) within the frame of the EVE (Evolution et variabilité du climat à léchelle globale) 2009-2011 project "RISCC: Rôle des Ice-Shelves dans le Changement Climatique" and the IMAGO (Interactions multiples dans l'atmosphère, la glace et l'océan) 2013 project "ICE-BIO-RAM : Impact des Changements Environnementaux sur la BIOdiversité marine lors des Réchauffements Abrupts du cliMat", the latter being also supported by the INTERRVIE (Interactions Terre/Vie) - TS (Terre solide) INSU program. We also acknowledge financial support and use of the facilities of the ARTEMIS ${ }^{14} \mathrm{C}$ AMS French INSU project. The research leading to these results also benefited from funding from the European Union's Seventh Framework Programme (FP7/2007-2013) under grant agreement no. 243908, "Past4Future. Climate change Learning from the past climate". This is a Past4Future contribution.

We thank M.-H. Castera, I. Billy, P. Lebleu, O. Ther, M. Georget for invaluable technical assistance at the EPOC laboratory. We also warmly thank L. Londeix, D. Swingedouw and M. Cremer for their valuable advice and enriching discussions, which contributed to greatly improving the present study. Data provided in this paper can be obtained through written request to $M$. Wary.

This is a U.M.R. EPOC 5805 (Université de Bordeaux C.N.R.S.) contribution.

Edited by: V. Rath

\section{References}

Alvarez-Solas, J., Charbit, S., Ritz, C., Paillard, D., Ramstein, G., and Dumas, C.: Links between ocean temperature and iceberg discharge during Heinrich events, Nat. Geosci., 3, 122-126, 2010.

Andersen, K. K., Svensson, A., Johnsen, S. J., Rasmussen, S. O., Bigler, M., Röthlisberger, R., Ruth, U., Siggaard-Andersen, M. L., Peder Steffensen, J., Dahl-Jensen, D., Vinther, B. M., and Clausen, H. B.: The Greenland Ice Core Chronology 2005, 1542 ka. Part 1: constructing the time scale, Quaternary Sci. Rev., 25, 3246-3257, 2006.

Antonov, J. I., Seidov, D., Boyer, T. P., Locarnini, R. A., Mishonov, A. V., Garcia, H. E., Baranova, O. K., Zweng, M. M., and Johnson, D. R.: World Ocean Atlas 2009, Volume 2: Salinity, edited by: Levitus, S., NOAA Atlas NESDIS 69, U.S. Government Printing Office, Washington, D.C., 184 pp., 2010.

Ballini, M., Kissel, C., Colin, C., and Richter, T.: Deepwater mass source and dynamic associated with rapid climatic variations during the last glacial stage in the North Atlantic : a multi-proxy investigation of the detrital fraction of deep-sea sediments., Geochem. Geophy. Geosy., 7, Q02N01, doi:10.1029/2005GC001070, 2006.

Banks, R. E.: The cold layer in the Gulf of St. Lawrence, J. Geophys. Res., 71, 1603-1610, 1966.

Bianchi, G. G. and McCave, I. N.: Holocene periodicity in North Atlantic climate and deep-ocean flow south of Iceland, Nature, 397, 515-517, 1999.

Boldreel, L. O., Andersen, M. S., and Kuijpers, A.: Neogene seismic facies and deep-water gateways in the Faeroe Bank area, NE Atlantic, Mar. Geol., 152, 129-140, 1998.

Bond, G., Broecker, W., Johnsen, S., McManus, J., Labeyrie, L., Jouzel, J., and Bonani, G.: Correlations between climate records from North Atlantic sediments and Greenland ice, Nature, 365, 143-147, 1993.

Bond, G. C. and Lotti, R.: Iceberg discharges into the North Atlantic on millennial time scales during the last glaciation, Science, 267, 1005-1010, 1995.

Borenäs, K. and Lundberg, P.: The Faroe-Bank Channel deep-water overflow, Deep-Sea Res. Pt. II, 51, 335-350, 2004

Cacho, I., Grimalt, J. O., Sierro, F. J., Shackleton, N., and Canals, M.: Evidence for enhanced Mediterranean thermohaline circulation during rapid climatic coolings, Earth Planet. Sc. Lett., 183, 417-429, 2000.

Caley, T. and Roche, D. M.: d180 water isotope in the iLOVECLIM model (version 1.0) - Part 3: A palaeo-perspective based on present-day data-model comparison for oxygen stable isotopes in carbonates, Geosci. Model Dev., 6, 1505-1516, doi:10.5194/gmd-6-1505-2013, 2013.

Carstens, J., Hebbeln, D., and Wefer, G.: Distribution of planktic foraminifera at the ice margin in the Arctic (Fram Strait), Mar. Micropaleontol., 29, 257-269, 1997.

Caulle, C., Penaud, A., Eynaud, F., Zaragosi, S., Roche, D. M., Michel, E., Boulay, S., and Richter, T.: Sea-surface hydrographical conditions off South Faeroes and within the North-Eastern North Atlantic through MIS 2: The response of dinocysts, J. Quaternary Sci., 28, 217-228, 2013.

Dansgaard, W., Johnsen, S. J., Clausen, H. B., Dahl-Jensen, D., Gundestrup, N. S., Hammer, C. U., Hvidberg, C. S., Steffensen, 
J. P., Sveinbjörnsdottir, A. E., Jouzel, J., and Bond, G.: Evidence for general instability of past climate from a 250-kyr ice-core record, Nature, 364, 218-220, 1993.

de Vernal, A., Eynaud, F., Henry, M., Hillaire-Marcel, C., Londeix, L., Mangin, S., Matthiessen, J., Marret, F., Radi, T., Rochon, A., Solignac, S., and Turon, J. L.: Reconstruction of sea-surface conditions at middle to high latitudes of the Northern Hemisphere during the Last Glacial Maximum (LGM) based on dinoflagellate cyst assemblages, Quaternary Sci. Rev., 24, 897-924, 2005.

de Vernal, A., Rosell-Melé, A., Kucera, M., Hillaire-Marcel, C., Eynaud, F., Weinelt, M., Dokken, T., and Kageyama, M.: Comparing proxies for the reconstruction of LGM sea-surface conditions in the northern North Atlantic, Quaternary Sci. Rev., 25, 28202834, 2006.

Dickson, A. J., Austin, W. E. N., Hall, I. R., Maslin, M. A., and Kucera, M.: Centennial-scale evolution of Dansgaard-Oeschger events in the northeast Atlantic Ocean between 39.5 and 56.5 ka B.P, Paleoceanography, 23, PA3206, doi:10.1029/2008PA001595, 2008.

Dokken, T. M., Nisancioglu, K. H., Li, C., Battisti, D. S., and Kissel, C.: Dansgaard-Oeschger cycles: Interactions between ocean and sea ice intrinsic to the Nordic seas, Paleoceanography, 28, 491502, 2013.

Duplessy, J. C., Labeyrie, L., Juillet-Leclerc, A., Maitre, F., Duprat, J., and Sarnthein, M.: Surface salinity reconstruction of the North Atlantic Ocean during the Last Glacial maximum, Oceanol. Acta, 14, 311-324, 1991.

Ehlers, J. and Gibbard, P. L.: The extent and chronology of Cenozoic Global Glaciation, Quatern. Intern., 164-165, 6-20, 2007.

Elliot, M., Labeyrie, L., Bond, G., Cortijo, E., Turon, J. L., Tisnerat, N., and Duplessy, J. C.: Millennial-scale iceberg discharges in the Irminger Basin during the last glacial period: Relationship with the Heinrich events and environmental settings, Paleoceanography, 13, 433-446, 1998.

Elliot, M., Labeyrie, L., Dokken, T., and Manthe, S.: Coherent patterns of ice-rafted debris deposits in the Nordic regions during the last glacial (10-60 ka), Earth Planet. Sc. Lett., 194, 151-163, 2001.

Elliot, M., Labeyrie, L., and Duplessy, J. C.: Changes in North Atlantic deep-water formation associated with the Dansgaard Oeschger temperature oscillations (60-10 ka), Quaternary Sci. Rev., 21, 1153-1165, 2002.

Epstein, S. and Mayeda, T.: Variation of ${ }^{18} \mathrm{O}$ content of waters from natural sources, Geochim. Cosmochim. Ac., 4, 213-224, 1953.

Eynaud, F., Turon, J. L., Matthiessen, J., Kissel, C., Peypouquet, J. P., De Vernal, A., and Henry, M.: Norwegian sea-surface palaeoenvironments of marine oxygen-isotope stage 3: The paradoxical response of dinoflagellate cysts, J. Quaternary Sci., 17, 349-359, 2002.

Eynaud, F., Zaragosi, S., Scourse, J. D., Mojtahid, M., Bourillet, J. F., Hall, I. R., Penaud, A., Locascio, M., and Reijonen, A.: Deglacial laminated facies on the NW European continental margin: The hydrographic significance of British-Irish Ice Sheet deglaciation and Fleuve Manche paleoriver discharges, Geochem. Geophy. Geosys., 8, Q06019, doi:10.1029/2006GC001496, 2007.

Eynaud, F., Rossignol, L., and Gasparotto, M.-C.: Planktic foraminifera throughout the Pleistocene: from cell to populations to past marine hydrology, in Foraminifera: Classification, Biol- ogy, and Evolutionary Significance, edited by: Georgescu, M. D., Nova Science Publishers, New York, NY, 2013.

Ganopolski, A. and Rahmstorf, S.: Rapid changes of glacial climate simulated in a coupled climate model, Nature, 409, 153$158,2001$.

Goodman, D. K.: Dinoflagellate "communities"; from the lower Eocene Nanjemoy formation of Maryland, U.S.A, Palynology, 3, 169-190, 1979.

Guiot, J. and de Vernal, A.: Transfer functions: methods for quantitative paleoceanography based on microfossils, Chapt. thirteen, in: Developments in Marine Geology, edited by: Hillaire-Marcel, C. and De Vernal, A., Elsevier, 1, 523-563, 2007.

Guiot, J. and de Vernal, A.: Is spatial autocorrelation introducing biases in the apparent accuracy of paleoclimatic reconstructions?, Quaternary Sci. Rev., 30, 1965-1972, 2011a.

Guiot, J. and de Vernal, A.: QSR Correspondence "Is spatial autocorrelation introducing biases in the apparent accuracy of palaeoclimatic reconstructions?" Reply to Telford and Birks, Quaternary Sci. Rev., 30, 3214-3216, 2011 b.

Hall, I. R., Colmenero-Hidalgo, E., Zahn, R., Peck, V. L., and Hemming, S. R.: Centennial- to millennial-scale ice-ocean interactions in the subpolar northeast Atlantic 18-41 kyr ago, Paleoceanography, 26, PA2224, doi:10.1029/2010PA002084, 2011.

Hansen, B. and Osterhus, S.: North Atlantic-Nordic Sea exchanges, Prog. Oceanogr., 45, 109-208, 2000.

Hayes, A., Kucera, M., Kallel, N., Sbaffi, L., and Rohling, E. J.: Glacial Mediterranean sea surface temperatures based on planktonic foraminiferal assemblages, Quaternary Sci. Rev., 24, 9991016, 2005.

Heinrich, H.: Origin and consequences of cyclic ice rafting in the Northeast Atlantic Ocean during the past 130,000 years, Quaternary Res., 29, 142-152, 1988.

Hodell, D. A., Minth, E. K., Curtis, J. H., McCave, I. N., Hall, I. R., Channell, J. E. T., and Xuan, C.: Surface and deep-water hydrography on Gardar Drift (Iceland Basin) during the last interglacial period, Earth Planet. Sc. Lett., 288, 10-19, 2009.

Howe, J. A., Stoker, M. S., Masson, D. G., Pudsey, C. J., Morris, P., Larter, R. D., and Bulat, J.: Seabed morphology and the bottomcurrent pathways around Rosemary Bank seamount, northern Rockall Trough, North Atlantic, Mar. Petrol. Geol., 23, 165-181, 2006.

Jonkers, L., Brummer, G. J. A., Peeters, F. J. C., Van Aken, H. M., and De Jong, M. F.: Seasonal stratification, shell flux, and oxygen isotope dynamics of leftcoiling N. pachyderma and T. quinqueloba in the western subpolar North Atlantic, Paleoceanography, 25, PA2204, doi:10.1029/2009PA001849, 2010.

Kissel, C., Laj, C., Labeyrie, L., Dokken, T., Voelker, A., and Blamart, D.: Rapid climatic variations during marine isotopic stage 3: Magnetic analysis of sediments from Nordic Seas and North Atlantic, Earth Planet. Sc. Lett., 171, 489-502, 1999.

Kissel, C., Laj, C., Piotrowski, A. M., Goldstein, S. L., and Hemming, S. R.: Millennial-scale propagation of Atlantic deep waters to the glacial Southern Ocean, Paleoceanography, 23, PA2102, doi:10.1029/2008PA001624, 2008.

Kissel, C., Laj, C., Mulder, T., Wandres, C., and Cremer, M.: The magnetic fraction: A tracer of deep water circulation in the North Atlantic, Earth Planet. Sc. Lett., 288, 444-454, 2009.

Kucera, M., Weinelt, M., Kiefer, T., Pflaumann, U., Hayes, A., Chen, M. T., Mix, A. C., Barrows, T. T., Cortijo, E., Duprat, J., 
Juggins, S., and Waelbroeck, C.: Reconstruction of sea-surface temperatures from assemblages of planktonic foraminifera: Multi-technique approach based on geographically constrained calibration data sets and its application to glacial Atlantic and Pacific Oceans, Quaternary Sci. Rev., 24, 951-998, 2005.

Kuijpers, A., Andersen, M. S., Kenyon, N. H., Kunzendorf, H., and Van Weering, T. C. E.: Quaternary sedimentation and Norwegian Sea overflow pathways around Bill Bailey Bank, northeastern Atlantic, Mar. Geol., 152, 101-127, 1998a.

Kuijpers, A., Troelstra, S. R., Wisse, M., Nielsen, S. H., and Van Weering, T. C. E.: Norwegian Sea overflow variability and NE Atlantic surface hydrography during the past 150,000 years, Mar. Geol., 152, 75-99, 1998b.

Kuijpers, A., Hansen, B., Hühnerbach, V., Larsen, B., Nielsen, T., and Werner, F.: Norwegian Sea overflow through the FaroeShetland gateway as documented by its bedforms, Mar. Geol., 188, 147-164, 2002.

Kullenberg, G.: Physical Oceanography, in: The Baltic Sea, edited by: Voipio, A., Elsevier Oceanography Series, Chapt. 3, Elsevier, Amsterdam, the Netherlands, 135-181, 1981.

Labeyrie, L. and Cortijo, E.: Physical properties of sediment core MD99-2281, doi:10.1594/PANGAEA.253612, 2005.

Labeyrie, L., Cortijo, E., and Jansen, E.: Rapport scientifique de la mission INTERPOLE MD99-114/812 IMAGES V, in: Les Rapports de Campagne à la Mer à bord du Marion Dufresne, IPEV, Brest, 1999.

Laj, C., Kissel, C., Mazaud, A., Channell, J. E. T., and Beer, J.: North Atlantic palaeointensity stack since $75 \mathrm{ka}$ (NAPIS-75) and the duration of the Laschamp event, Philos. T. R. Soc. A, 358, 1009-1025, 2000.

Levine, R. C. and Bigg, G. R.: Sensitivity of the glacial ocean to Heinrich events from different iceberg sources, as modeled by a coupled atmosphere-iceberg-ocean model, Paleoceanography, 23, PA4213, doi:10.1029/2008PA001613, 2008.

Locarnini, R. A., Mishonov, A. V., Antonov, J. I., Boyer, T. P., Garcia, H. E., Baranova, O. K., Zweng, M. M., and Johnson, D. R.: World Ocean Atlas 2009, Volume 1: Temperature, edited by : Levitus, S., NOAA Atlas NESDIS 68, U.S. Government Printing Office, Washington, D.C., 184 pp., 2010.

Londeix, L., Benzakour, M., Suc, J. P., and Turon, J. L.: Messinian palaeoenvironments and hydrology in Sicily (Italy): The dinoflagellate cyst record, Geobios, 40, 233-250, 2007.

Malaizé, B. and Caley, T.: Sea surface salinity reconstruction as seen with foraminifera shells: Methods and cases studies, Eur. Phys. J., 1, 177-188, 2009.

Manabe, S. and Stouffer, R. J.: Simulation of abrupt climate change induced by freshwater input to the North Atlantic Ocean, Nature, 378, 165-167, 1995.

Mary, Y., Eynaud, F., Zaragosi, S., Malaizé, B., Cremer, M., and Schmidt, S.: High frequency environmental changes and deposition processes in a $2 \mathrm{kyr}$-long sedimentological record from the Cap-Breton canyon (Bay of Biscay), Holocene, 25, 348-365, 2015.

Matsuzaki, K. M. R., Eynaud, F., Malaizé, B., Grousset, F. E., Tisserand, A., Rossignol, L., Charlier, K., and Jullien, E.: Paleoceanography of the Mauritanian margin during the last two climatic cycles: From planktonic foraminifera to African climate dynamics, Mar. Micropaleontol., 79, 67-79, 2011.
McCave, I. N.: Deep-sea sediment deposits and properties controlled by currents, Chapt. One, in: Developments in Marine Geology, edited by: Hillaire-Marcel, C. and De Vernal, A., Elsevier, 1, 19-62, 2007.

McCave, I. N., Manighetti, B., and Beveridge, N. A. S.: Circulation in the glacial North Atlantic inferred from grain-size measurements, Nature, 374, 149-152, 1995a.

McCave, I. N., Manighetti, B., and Robinson, S. G.: Sortable silt and fine sediment size/composition slicing: parameters for palaeocurrent speed and palaeoceanography, Paleoceanography, 10, 593-610, 1995b.

Moros, M., Endler, R., Lackschewitz, K. S., Wallrabe-Adams, H. J., Mienert, J., and Lemke, W.: Physical properties of Reykjanes Ridge sediments and their linkage to high-resolution Greenland Ice Sheet Project 2 ice core data, Paleoceanography, 12, 687695, 1997.

Moros, M., Kuijpers, A., Snowball, I., Lassen, S., Bäckström, D., Gingele, F., and McManus, J.: Were glacial iceberg surges in the North Atlantic triggered by climatic warming?, Mar. Geol., 192, 393-417, 2002.

Orvik, K. A. and Niiler, P.: Major pathways of Atlantic water in the northern North Atlantic and Nordic Seas toward Arctic, Geophys. Res. Lett., 29, 2-1, 2002.

Peck, V. L., Hall, I. R., Zahn, R., and Elderfield, H.: Millennialscale surface and subsurface paleothermometry from the northeast Atlantic, 55-8 ka BP, Paleoceanography, 23, PA3221, doi:10.1029/2008PA001631, 2008.

Penaud, A., Eynaud, F., Voelker, A., Kageyama, M., Marret, F., Turon, J. L., Blamart, D., Mulder, T., and Rossignol, L.: Assessment of sea surface temperature changes in the Gulf of Cadiz during the last $30 \mathrm{ka}$ : implications for glacial changes in the regional hydrography, Biogeosciences, 8, 2295-2316, doi:10.5194/bg-82295-2011, 2011.

Prins, M. A., Bouwer, L. M., Beets, C. J., Troelstra, S. R., Weltje, G. J., Kruk, R. W., Kuijpers, A., and Vroon, P. Z.: Ocean circulation and iceberg discharge in the glacial North Atlantic: Inferences from unmixing of sediment size distributions, Geology, 30, 555558, 2002.

Rahmstorf, S.: Ocean circulation and climate during the past 120,000 years, Nature, 419, 207-214, 2002.

Rasmussen, T. L. and Thomsen, E.: The role of the North Atlantic Drift in the millennial timescale glacial climate fluctuations, Palaeogeogr. Palaeocl., 210, 101-116, 2004

Rasmussen, T. L. and Thomsen, E.: Warm Atlantic surface water inflow to the Nordic seas 34-10 calibrated ka B.P, Paleoceanography, 23, PA1201, doi:10.1029/2007PA001453, 2008.

Rasmussen, T. L. and Thomsen, E.: Ventilation changes in intermediate water on millennial time scales in the SE Nordic seas, 65-14 kyr BP, Geophys. Res. Lett., 36, L01601, doi:10.1029/2008GL036563, 2009.

Rasmussen, T. L., Thomsen, E., Labeyrie, L., and Van Weering, T. C. E.: Circulation changes in the Faeroe-Shetland Channel correlating with cold events during the last glacial period (58-10 ka), Geology, 24, 937-940, 1996a.

Rasmussen, T. L., Thomsen, E., Van Weering, T. C. E., and Labeyrie, L.: Rapid changes in surface and deep water conditions at the Faeroe Margin during the last 58,000 years, Paleoceanography, 11, 757-771, 1996b. 
Rasmussen, T. L., Van Weering, T. C. E., and Labeyrie, L.: Climatic instability, ice sheets and ocean dynamics at high northern latitudes during the last glacial period (58-10 KA BP), Quaternary Sci. Rev., 16, 71-80, 1997.

Rasmussen, T. L., Balbon, E., Thomsen, E., Labeyrie, L., and Van Weering, T. C. E.: Climate records and changes in deep outflow from the Norwegian Sea $\sim 150-55 \mathrm{ka}$, Terra Nova, 11, 61-66, 1999.

Rasmussen, T. L., Thomsen, E., Troelstra, S. R., Kuijpers, A., and Prins, M. A.: Millennial-scale glacial variability versus Holocene stability: Changes in planktic and benthic foraminifera faunas and ocean circulation in the North Atlantic during the last 60 000 years, Mar. Micropaleontol., 47, 143-176, 2002a.

Rasmussen, S. O., Bigler, M., Blockley, S. P., Blunier, T., Buchardt, S. L., Clausen, H. B., Cvijanovic, I., Dahl-Jensen, D., Johnsen, S. J., Fischer, H., Gkinis, V., Guillevic, M., Hoek, W. Z., Lowe, J. J., Pedro, J. B., Popp, T., Seierstad, I. K., Steffensen, J. P., Svensson, A. M., Vallelonga, P., Vinther, B. M., Walker, M. J. C., Wheatley, J. J., and Winstrup, M.: A stratigraphic framework for abrupt climatic changes during the Last Glacial period based on three synchronized Greenland ice-core records: Refining and extending the INTIMATE event stratigraphy, Quaternary Sci. Rev., 106, 14-28, 2014.

Rochon, A., de Vernal, A., Turon, J.-L., Matthiessen, J., and Head, M. J. (Eds.): Distribution of dinoflagellate cysts in surface sediments from the North Atlantic Ocean and adjacent basins and quantitative reconstruction of sea-surface parameters, AASP special pub., Dallas, Texas, 1999.

Sánchez Goñi, M. F. and Harrison, S. P.: Millennial-scale climate variability and vegetation changes during the Last Glacial: Concepts and terminology, Quaternary Sci. Rev., 29, 2823-2827, 2010.

Sánchez Goñi, M. F., Bakker, P., Desprat, S., Carlson, A. E., Van Meerbeeck, C. J., Peyron, O., Naughton, F., Fletcher, W. J., Eynaud, F., Rossignol, L., and Renssen, H.: European climate optimum and enhanced Greenland melt during the last interglacial, Geology, 40, 627-630, 2012.

Sánchez Goñi, M. F., Bard, E., Landais, A., Rossignol, L., and D'Errico, F.: Air-sea temperature decoupling in western Europe during the last interglacial-glacial transition, Nat. Geosci., 6, 837-841, 2013.

Schäfer-Neth, C. and Manschke, A.: ,WOA sample tool, available at: http://www.geo.uni-bremen.de/geomod/staff/csn/woasample. html (last access: 31 October 2015), 2002.

Schiebel, R., Waniek, J., Bork, M., and Hemleben, C.: Planktic foraminiferal production stimulated by chlorophyll redistribution and entrainment of nutrients, Deep-Sea Res. Pt. I, 48, 721-740, 2001.

Schlitzer, R.: Ocean Data View, available at: http://odv.awi.de (last access: 8 April 2014), 2012.

Scourse, J. D., Haapaniemi, A. I., Colmenero-Hidalgo, E., Peck, V. L., Hall, I. R., Austin, W. E. N., Knutz, P. C., and Zahn, R.: Growth, dynamics and deglaciation of the last British-Irish ice sheet: the deep-sea ice-rafted detritus record, Quaternary Sci. Rev., 28, 3066-3084, 2009.
Shackleton, N. J.: Attainment of isotopic equilibrium between ocean water and the benthic foraminifera genus Uvigerina: isotopic changes in the ocean during the Last Glacial, in: Methodes Quantitatives d'Étude des Variations du Climat au Cours du Pleistocène, edited by: Labeyrie, L., no. 219, Colloques Internationaux du CNRS, Paris, 203-209, 1974.

Shannon, C. E. and Weaver, W.: The Mathematical Theory of Information, University of Illinois Press, Urbana, 144 pp., 1949.

Siddall, M., Rohling, E. J., Thompson, W. G., and Waellbroeck, C.: Marine isotope stage 3 sea level fluctuations: Data synthesis and new outlook, Rev. Geophys., 46, RG4003, doi:10.1029/2007RG000226, 2008.

Simstich, J., Sarnthein, M., and Erlenkeuser, H.: Paired $\delta 180$ signals of Neogloboquadrina pachyderma (s) and Turborotalita quinqueloba show thermal stratification structure in Nordic Seas, Mar. Micropaleontol., 48, 107-125, 2003.

Snowball, I. and Moros, M.: Saw-tooth pattern of North Atlantic current speed during Dansgaard-Oeschger cycles revealed by the magnetic grain size of Reykjanes Ridge sediments at $59^{\circ} \mathrm{N}, \mathrm{Pa}-$ leoceanography, 18, 4-1, 2003.

Staines-Urías, F., Kuijpers, A., and Korte, C.: Evolution of subpolar North Atlantic surface circulation since the early Holocene inferred from planktic foraminifera faunal and stable isotope records, Quaternary Sci. Rev., 76, 66-81, 2013.

Stanford, J. D., Rohling, E. J., Bacon, S., and Holliday, N. P.: A review of the deep and surface currents around Eirik Drift, south of Greenland: Comparison of the past with the present, Global Planet. Change, 79, 244-254, 2011.

Svensson, A., Andersen, K. K., Bigler, M., Clausen, H. B., DahlJensen, D., Davies, S. M., Johnsen, S. J., Muscheler, R., Parrenin, F., Rasmussen, S. O., Röthlisberger, R., Seierstad, I., Steffensen, J. P., and Vinther, B. M.: A 60000 year Greenland stratigraphic ice core chronology, Clim. Past, 4, 47-57, doi:10.5194/cp-4-472008, 2008.

Tolderlund, D. S. and Bé, A. W. H.: Seasonal Distribution of Planktonic Foraminifera in the Western North Atlantic, Micropaleontology, 17, 297-329, 1971.

Toucanne, S., Mulder, T., Schönfeld, J., Hanquiez, V., Gonthier, E., Duprat, J., Cremer, M., and Zaragosi, S.: Contourites of the Gulf of Cadiz: A high-resolution record of the paleocirculation of the Mediterranean outflow water during the last 50,000 years, Palaeogeogr. Palaeocl., 246, 354-366, 2007.

Van Kreveld, S., Sarnthein, M., Erlenkeuser, H., Grootes, P., Jung, S., Nadeau, M. J., Pflaumann, U., and Voelker, A.: Potential links between surging ice sheets, circulation changes, and the Dansgaard-Oeschger cycles in the Irmiger Sea, 60-80 kyr, Paleoceanography, 15, 425-442, 2000.

Voelker, A. H. L., Lebreiro, S. M., Schönfeld, J., Cacho, I., Erlenkeuser, H., and Abrantes, F.: Mediterranean outflow strengthening during northern hemisphere coolings: A salt source for the glacial Atlantic?, Earth Planet. Sc. Lett., 245, 39-55, 2006.

Waelbroeck, C., Labeyrie, L., Michel, E., Duplessy, J. C., McManus, J. F., Lambeck, K., Balbon, E., and Labracherie, M.: Sealevel and deep water temperature changes derived from benthic foraminifera isotopic records, Quaternary Sci. Rev., 21, 295-305, 2002. 
Wolff, E. W., Chappellaz, J., Blunier, T., Rasmussen, S. O., and Svensson, A.: Millennial-scale variability during the last glacial: The ice core record, Quaternary Sci. Rev., 29, 2828-2838, 2010.
Zumaque, J., Eynaud, F., Zaragosi, S., Marret, F., Matsuzaki, K. M., Kissel, C., Roche, D. M., Malaizé, B., Michel, E., Billy, I., Richter, T., and Palis, E.: An ocean-ice coupled response during the last glacial: a view from a marine isotopic stage 3 record south of the Faeroe Shetland Gateway, Clim. Past, 8, 1997-2017, doi:10.5194/cp-8-1997-2012, 2012. 